\title{
Elevated nitrogen-containing particles observed in Asian dust aerosol samples collected at the marine boundary layer of the Bohai Sea and the Yellow Sea
}

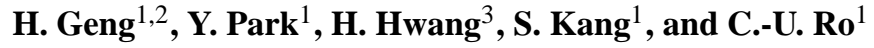 \\ ${ }^{1}$ Department of Chemistry, Inha University, Incheon, 402-751, Korea \\ ${ }^{2}$ Research Center of Environmental Science and Engineering, Shanxi University, Taiyuan, 030006, China \\ ${ }^{3}$ Korea Polar Research Institute, Incheon, 406-840, Korea
}

Received: 23 April 2009 - Published in Atmos. Chem. Phys. Discuss.: 22 June 2009

Revised: 27 August 2009 - Accepted: 3 September 2009 - Published: 22 September 2009

\begin{abstract}
Low- $Z$ particle electron probe $X$-ray microanalysis (low- $Z$ particle EPMA) shows powerful advantages for the characterization of ambient particulate matter in environmental and geological applications. By the application of the low- $Z$ particle EPMA single particle analysis, an overall examination of 1800 coarse and fine particles (aerodynamic diameters: $2.5-10 \mu \mathrm{m}$ and $1.0-2.5 \mu \mathrm{m}$, respectively) in six samples collected on 28 April-1 May 2006 in the marine boundary layer (MBL) of the Bohai Sea and Yellow Sea was conducted. Three samples (D1, D2, and D3) were collected along the Bohai Bay, Bohai Straits, and Yellow Sea near Korea during an Asian dust storm event while the other three samples (N3, N2, and N1) were collected on non-Asian dust (NAD) days. Based on X-ray spectral and secondary electron image data, 15 different types of particles were identified, in which soil-derived particles were encountered with the largest frequency, followed by $(\mathrm{C}, \mathrm{N}, \mathrm{O})$-rich droplets (likely the mixture of organic matter and $\mathrm{NH}_{4} \mathrm{NO}_{3}$ ), particles of marine origin, and carbonaceous, Fe-rich, fly ash, and (C, N, O, S)-rich droplet particles. Results show that during the Asian dust storm event relative abundances of the $(\mathrm{C}, \mathrm{N}, \mathrm{O})$-rich droplets and the nitrate-containing secondary soil-derived particles were markedly increased (on average by a factor of 4.5 and 2 , respectively in $\mathrm{PM}_{2.5-10}$ fraction and by a factor of 1.9 and 1.5 , respectively in $\mathrm{PM}_{1.0-2.5}$ fraction) in the MBL of the Bohai Sea and Yellow Sea, implying that Asian dust aerosols in springtime are an important carrier of gaseous inorganic nitrogen species, especially $\mathrm{NO}_{\mathrm{x}}$ (or $\mathrm{HNO}_{3}$ ) and $\mathrm{NH}_{3}$.
\end{abstract}

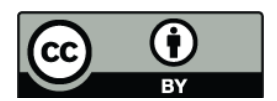

Correspondence to: C.-U. Ro (curo@inha.ac.kr)

\section{Introduction}

The Asian dust storm event is a seasonal meteorological phenomenon that mostly originates in the deserts of Mongolia and Northern China and Kazakhstan (Sullivan et al., 2007). Nearly every spring, usually from March to May, Asian dust aerosols will be carried eastward by strong winds and pass over Eastern China, North and South Korea, Japan, open seas and oceans, and even arrive in the United States (Bishop, et al., 2002; Zhao, et al., 2008). During longrange transport, Asian dust aerosols can react with a diversity of chemical species, coagulate with other particles, and/or provide reaction sites in the atmosphere, so that they potentially carry many chemical species along with the original soil components, and the physical and chemical properties of the dust particles may change (Hwang et al., 2008). These change/coagulation processes affect the optical and hygroscopic properties of Asian dust particles, which are related to important but uncertain direct impacts on climate change, radiative budget, and possibly rainfall patterns (Ramanathan, et al., 2001; Jickells et al., 2005; Su et al., 2008), and they also affect the cycles and chemical balances of important trace gases (e.g. $\mathrm{SO}_{2}, \mathrm{NO}_{\mathrm{x}}, \mathrm{O}_{3}$ ), acid deposition, and the $\mathrm{pH}$ of precipitation (Sullivan et al., 2007). Thus, increasing attention has been devoted to the study of modification of the physicochemical properties of Asian dust particles during long-range transport. It was observed that Asian dust aerosols collected in Korea experienced reactions with $\mathrm{NO}_{\mathrm{x}}$ and $\mathrm{SO}_{2}$ so that a number of nitrate- or sulfatecontaining particles such as $\mathrm{NaNO}_{3}, \mathrm{Na}_{2} \mathrm{SO}_{4}, \mathrm{Ca}\left(\mathrm{NO}_{3}\right)_{2}$, and $\left(\mathrm{NH}_{4}\right)_{2} \mathrm{SO}_{4}$ were encountered (Hwang and Ro, 2006; Ro et al., 2005). In Japan, Hong Kong, Taiwan, and even

Published by Copernicus Publications on behalf of the European Geosciences Union. 
mainland China (from the source area to Chinese coastal regions), Asian dust particles have been reported to undergo significant chemical modifications through mixing with sea salts or reacting with anthropogenic air pollutants (Fang et al., 1999; Ma et al., 2001; Wang et al., 2007; Lin et al., 2008).

Through "bulk" and "single-particle" analyses, the chemical compositional characteristics of Asian dust aerosol particles in the regions surrounding the Yellow Sea have also been investigated (Lee et al., 2002; Hwang and Ro, 2006; Zhang et al., 2007), but few reports have been published on compositional modification of aerosol particles in the marine boundary layer (MBL) of the Bohai Sea and Yellow Sea during Asian dust storm events. Owing to a lack of the direct observations, some conclusions on the interactions among mineral Asian dust, sea salts, and anthropogenic air pollutants (e.g. ammonium, and sulfur or nitrogen oxides species) in the MBL had to rely on speculation to some extent (Jeong and Park, 2008; Nishikawa et al., 1991; Park et al., 2003). Jeong and Park (2008) suggested that the favorable areas for gas (e.g. $\mathrm{SO}_{2}, \mathrm{NO}_{\mathrm{x}}$ ) - aerosol interaction during Asian dust storm events were the downstream regions where relative humidity is relatively high. Nishikawa et al. (1991) attributed the increase of concentrations of $\mathrm{SO}_{4}^{2-}$ and $\mathrm{NO}_{3}^{-}$in coarse mode particles over Japan to the interactions between gaseous acidic species and Asian dust particles over the marine area. From the observations that $\mathrm{SO}_{4}^{2-}$ and $\mathrm{NO}_{3}^{-}$were produced on the surface of Asian dust particles collected in Japan, but hardly formed on those particles over Beijing and Qingdao, China (Zhang and Iwasaka, 1999; Zhang et al., 2003; Fan et al., 1996; Ma et al., 2001), Park et al. (2003) suggested the higher concentrations of particulate $\mathrm{SO}_{4}^{2-}$ and $\mathrm{NO}_{3}^{-}$at Gosan, Korea, were generated during the transport of dust storms over the Yellow Sea. Therefore, it is critical and necessary to investigate the morphology and chemical composition of individual particles in the MBL of the Bohai Sea and Yellow Sea during Asian dust storm events in order to better understand the compositional modification of Asian dust aerosols in the atmosphere over China, Korea, and Japan.

Asian dust particles are chemically and morphologically heterogeneous (Wang et al., 2009). Their "average" compositions and aerodynamic diameters could be obtained by "bulk" analysis, but the exact aerosol mixing state and the chemical micro-processes in (or on) aerosol particles have been unambiguously determined by the application of single particle measurements (Tsuji et al., 2008). A recently developed electron probe $X$-ray microanalysis (EPMA) technique, named low- $Z$ particle EPMA, shows powerful advantages for the characterization of environmental and geological single particles (Ro et al., 2001a, 2005). By the application of the technique, the particle size distribution and the quantitative chemical compositions of individual particles have been obtained without a complicated sample pretreatment process, and many environmentally important atmospheric particles, e.g. sulfates, nitrates, ammonium, and carbonaceous species have been at least semi-quantitatively elucidated (Ro et al., 2000, 2005). Even the reaction process of Asian dust and sea salts with $\mathrm{NO}_{\mathrm{x}}$ or $\mathrm{SO}_{2}$ species were observed (Hwang and Ro, 2006). Hence, herein, low- $Z$ particle EPMA was utilized to examine the morphologies and chemical compositions of aerosol particles (including Asian dust aerosols) collected on a commercial ferryboat plying between Incheon, Korea and Tianjin, China from 28 April to 1 May 2006.

The objective of the present study is to characterize single aerosol particles collected in the MBL of the Bohai Sea and Yellow Sea in the springtime, and to investigate the influence of an Asian dust storm event on their compositional characteristics and relative abundances.

\section{Materials and methods}

\subsection{Samples}

Six sets of aerosol samples were collected on a ferryboat plying between the seaports of Incheon, Korea, and Tianjin, China. The sampling locations along the navigation route are shown in Fig. 1. The first sampling location (for samples D1 and N3) is on the Bohai Sea near the Tianjin seaport, representing the windward place where aerosols are influenced mostly by the continental outflow from mainland China; the second location (for samples D2 and N2) is at the demarcation area between the Bohai Sea and the Yellow Sea, which is regarded as a relatively clean marine environment (Feng et al., 2007); the third location (for samples D3 and N1) is on the Yellow Sea near the Incheon port, which is a leeward place where ambient aerosols are influenced by air masses from the Seoul-Incheon metropolitan area as well as from mainland China and the marine environment. Samples N1, $\mathrm{N} 2$, and N3 were collected when the ferryboat travelled from Kyonggi-man (near the Incheon port) to the Bohai Straits, and to the Bohai Bay (in the west of the Bohai Sea) on 28 and 29 April 2006 (Table 1). The other three samples D1, D2, and D3 were collected on 30 April and 1 May 2006 when the ferry returned from Tianjin to the Incheon seaport while an Asian dust storm event originating from Mongolia and northeast China was occurring (Fig. 2). In this work, Asian dust samples are designated as D1, D2, and D3 and non-Asian dust (NAD) samples designated as N1, N2, and N3.

The sources of aerosol particles for different samples were inferred through backward air-mass trajectories that were calculated via the HYbrid Single Particle Lagrangian Integrated Trajectory (HYSPLIT) model at the National Oceanographic and Atmospheric Administration (NOAA) Air Resources Laboratory's web server (http://www.arl.noaa.gov/ ready/hysplit4.html), as shown in Fig. 3. The air masses for samples D1, D2, and D3 mostly originated from Mongolia and northeast China, unlike those for N1 (air masses stayed around $36 \mathrm{~h}$ over the Yellow Sea), N2 (air masses at receptor heights of $300 \mathrm{~m}, 500 \mathrm{~m}$, and $1000 \mathrm{~m}$ originated from 
Table 1. Sampling date and time, sampling sites, and geographical traits of sampling locations.

\begin{tabular}{|c|c|c|c|}
\hline Sampling locations & Geographical traits & Sample & Sampling time (KST) \\
\hline $\begin{array}{l}\text { Yellow Sea } \\
\text { (near Incheon, Ko- } \\
\text { rea) }\end{array}$ & $\begin{array}{l}\text { The Yellow Sea, a semi-enclosed } \\
\text { marginal sea of the Northwest Pa- } \\
\text { cific Ocean, is surrounded by main- } \\
\text { land China and the Korean penin- } \\
\text { sula. To the northwest is the Bo- } \\
\text { hai Sea and to the south is the East } \\
\text { China Sea. }\end{array}$ & $\begin{array}{l}\text { N1 } \\
\text { D3 }\end{array}$ & $\begin{array}{l}\text { At 22:30 01:30 on } 28 \text { April } 2006 \\
\text { At } 07: 50 \sim 13: 00 \text { on } 1 \text { May } 2006\end{array}$ \\
\hline $\begin{array}{l}\text { Demarcation area } \\
\text { between Bohai and } \\
\text { Yellow Sea } \\
\text { (Bohai Straits) }\end{array}$ & $\begin{array}{l}\text { The Bohai Straits is located be- } \\
\text { tween Liaodong and Shandong } \\
\text { peninsula, connecting the Yellow } \\
\text { Sea and Bohai Sea. Several chan- } \\
\text { nels are formed as it is comparted } \\
\text { by many small islands. }\end{array}$ & $\begin{array}{l}\mathrm{N} 2 \\
\mathrm{D} 2\end{array}$ & $\begin{array}{l}\text { At 10:20 16:00 on } 29 \text { April } 2006 \\
\text { At 21:00 22:40 on } 30 \text { April } 2006\end{array}$ \\
\hline $\begin{array}{l}\text { Bohai Bay } \\
\text { (a part of the Bo- } \\
\text { hai Sea near Tian- } \\
\text { jin, China) }\end{array}$ & $\begin{array}{l}\text { The Bohai Sea is a nearly enclosed } \\
\text { interior sea with } 3784 \mathrm{~km} \text { of coast- } \\
\text { line and an average depth of } 18 \mathrm{~m} \text {. It } \\
\text { is the largest inland sea of China and } \\
\text { is composed of Liaodong Bay (to } \\
\text { the north), Bohai Bay (to the west), } \\
\text { Laizhou Bay (to the south), and the } \\
\text { middle sea. }\end{array}$ & $\begin{array}{l}\text { N3 } \\
\text { D1 }\end{array}$ & $\begin{array}{l}\text { At 16:00 19:00 on } 29 \text { April } 2006 \\
\text { At 14:00 17:05 on } 30 \text { April } 2006\end{array}$ \\
\hline
\end{tabular}

Note: Samples N1, N2, and N3 were collected on non-Asian dust (NAD) days while D1, D2, D3 were collected during an Asian dust storm event.

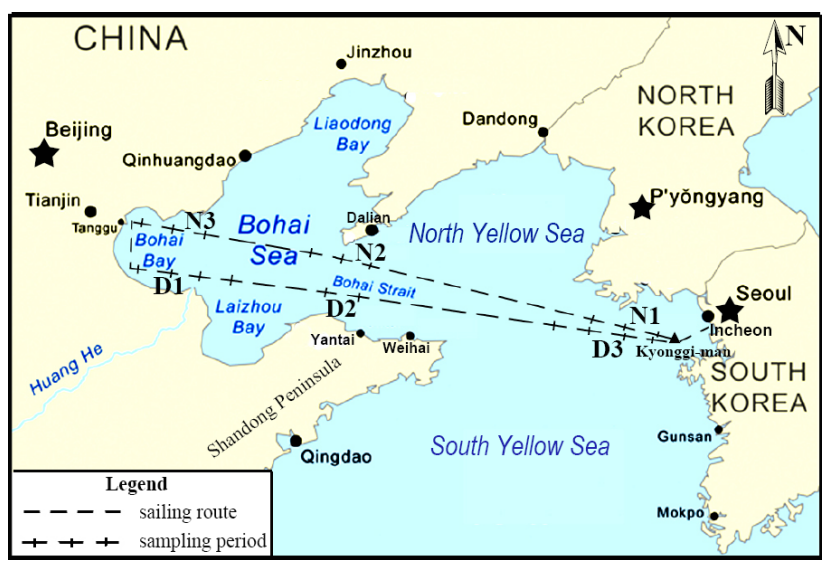

Fig. 1. Map of the ferryboat sailing route and sampling locations.

northeastern, eastern, and southeastern China, respectively), and N3 (air masses at heights of $300 \mathrm{~m}$ and $500 \mathrm{~m}$ originated from central and southern China and those at $1000 \mathrm{~m}$ were mainly from western China).

Particles were collected on Ag foils by a three-stage cascade Dekati $\mathrm{PM}_{10}$ impactor with aerodynamic cut-off diameters of $10 \mu \mathrm{m}, 2.5 \mu \mathrm{m}$, and $1.0 \mu \mathrm{m}$ at a $10 \mathrm{~L} / \mathrm{min}$ of flow rate. The impactor was set at the highest location on the ferryboat prow, about $15 \mathrm{~m}$ distant from sea level. For each sample, sampling durations varied to obtain an appropriate number of particles without overloading. The collected samples were put in plastic carriers, sealed, and stored before EPMA measurements. The stage 2 and 3 particles (2.5$10 \mu \mathrm{m}$ and $1.0-2.5 \mu \mathrm{m}$ size range, respectively), designated as " $\mathrm{PM}_{2.5-10}$ fraction" and " $\mathrm{PM}_{1.0-2.5}$ fraction" for convenience, were measured and analyzed.

\subsection{EPMA measurement}

The low- $Z$ particle EPMA measurement was carried out on a Hitachi S-3500N environmental scanning electron microscope equipped with an Oxford Link SATW ultra-thin window energy-dispersive X-ray spectrometry (EDX) detector. The resolution of the detector was $133 \mathrm{eV}$ for $\mathrm{Mn}-\mathrm{K}_{\alpha}$ $\mathrm{X}$-ray. The X-ray spectra were recorded under the control of EMAX Hitachi software. A $10 \mathrm{kV}$ accelerating voltage, $1.0 \mathrm{nA}$ of beam current, and a typical measuring time of $10 \mathrm{~s}$ were employed to ensure a low background level of spectra, a good sensitivity for low- $Z$ element analysis, and statistically sufficient counts in the X-ray spectra (Ro et al., 1999). The cold stage of the electron microprobe at liquid nitrogen temperature $\left(\sim-193^{\circ} \mathrm{C}\right)$ minimized contamination and lowered beam-damage effects on sensitive particles. Overall, 1800 particles were analyzed manually (150 particles for each stage sample). 


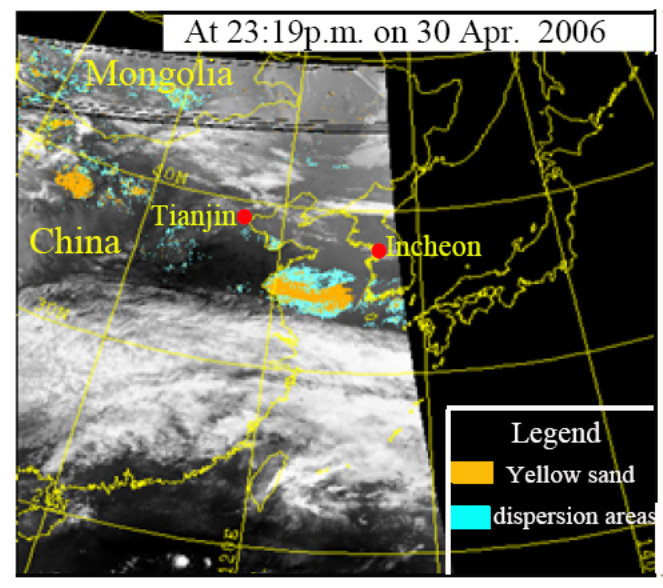

(a) 23:19 p.m. on 30 Apr. 2006 (KST)

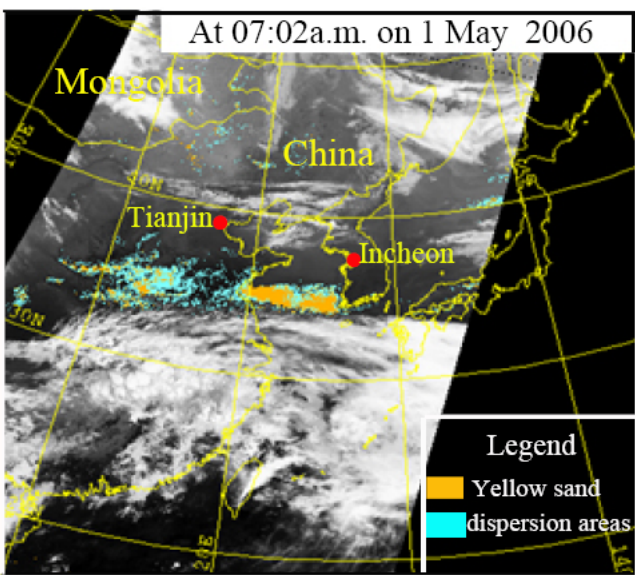

(b) 07:02 a.m. on 1 May $2006(\mathrm{KST})$

Fig. 2. GOES-9 Satellite images of the Asian dust storm event (provided by National Oceanic and Atmospheric Administration (NOAA), the United States). (Orange areas in GOES images denote high-density dust, and blue areas indicate dust dispersion areas. Red dots denote cities.)

\subsection{Data analysis}

The size and shape of each individual particle were input in the quantification procedure and the net X-ray intensities of the elements were obtained by non-linear least-squares fitting of the collected spectra through the AXIL program (Vekemans et al., 1994). A Monte Carlo calculation combined with reverse successive approximations was applied to determine the particles' elemental concentrations on the basis of the X-ray intensities (Ro et al., 2003). For standard particles, the quantification procedure provided results accurate within $12 \%$ relative deviations between the calculated and nominal elemental concentrations, except for $\mathrm{C}$ and $\mathrm{K}$ where the characteristic X-rays overlap with those from the Ag substrate (Ro et al., 2001b). The formula concentrations and the group distributions were rapidly and reliably determined by the "expert system" program (Ro et al., 2004).

\section{Results and discussion}

\subsection{Classification of individual particles based on their $\mathrm{X}$-ray spectra and secondary electron image (SEI)}

A brief explanation of the classification rules used to classify all the measured particles follows below. First, a particle is regarded as being composed of just one chemical species if this species accounts for at least a $90 \%$ atomic fraction, in which case the particle with one chemical species is regarded as a "pure" particle. Second, efforts were made to specify chemical species even for particles internally mixed with two or more species. Since many different types of internally mixed particles were identified, mixture particles were grouped on the basis of all the chemical species with a
$>10 \%$ formula fraction. Third, elements with an atomic concentration of less than $1.0 \%$ are not included in the procedure of chemical speciation because elements at trace levels cannot be reliably investigated (Ro et al., 2000, 2001a). On the basis of the above criteria, all the measured particles were classified into 15 types based on their X-ray spectral and SEI data, as shown in Fig. 4 and Table 2. The characteristics of each particle type are described below.

\section{(1) Primary and secondary soil-derived particles}

Primary soil-derived particles are those emitted directly from sources such as quarrying, agricultural harvesting, and entrainment of soils by the wind. Aluminosilicate (AlSi)containing, quartz $\left(\mathrm{SiO}_{2}\right)$, and calcite $\left(\mathrm{CaCO}_{3}\right) /$ dolomite $\left(\mathrm{CaMg}\left(\mathrm{CO}_{3}\right)_{2}\right)$ particles are the representative types, which usually appeared as irregular and bright on their SEIs (Fig. 4). The primary soil-derived particles can readily interact airborne sulfur and nitrogen oxides, especially in the presence of moisture (Lan et al., 2005; Hwang and Ro, 2006). These reaction or mixture products of primary particles with "secondary acids" were termed as secondary soilderived particles (Sullivan et al., 2007), and mainly included "reacted $\mathrm{CaCO}_{3} / \mathrm{CaMg}\left(\mathrm{CO}_{3}\right)_{2}$ " and "aluminosilicate $+(\mathrm{N}$, $\mathrm{S})$ ". (N, S) notation represents compounds containing either nitrates, sulfates, or both. The secondary aluminosilicate particles can be formed either through the reaction of cation ions in aluminosilicates with $\mathrm{H}_{2} \mathrm{SO}_{4}$ and/or $\mathrm{HNO}_{3}$, or from adsorption of $\mathrm{NH}_{4} \mathrm{NO}_{3}$ or $\mathrm{NH}_{4} \mathrm{HSO}_{4} /\left(\mathrm{NH}_{4}\right)_{2} \mathrm{SO}_{4}$ on particle surfaces that act as a reaction place for airborne $\mathrm{NH}_{3}$ and $\mathrm{H}_{2} \mathrm{SO}_{4}$ (or $\mathrm{HNO}_{3}$ ) (Sullivan et al., 2007), e.g. particles \#3, $\# 7$, \#12, \#21, \#28, \#39, \#44, \#48, \#51, \#58, \#84, and \#88 in Fig. 4. The secondary $\mathrm{CaCO}_{3} / \mathrm{CaMg}\left(\mathrm{CO}_{3}\right)_{2}$ particles contain 

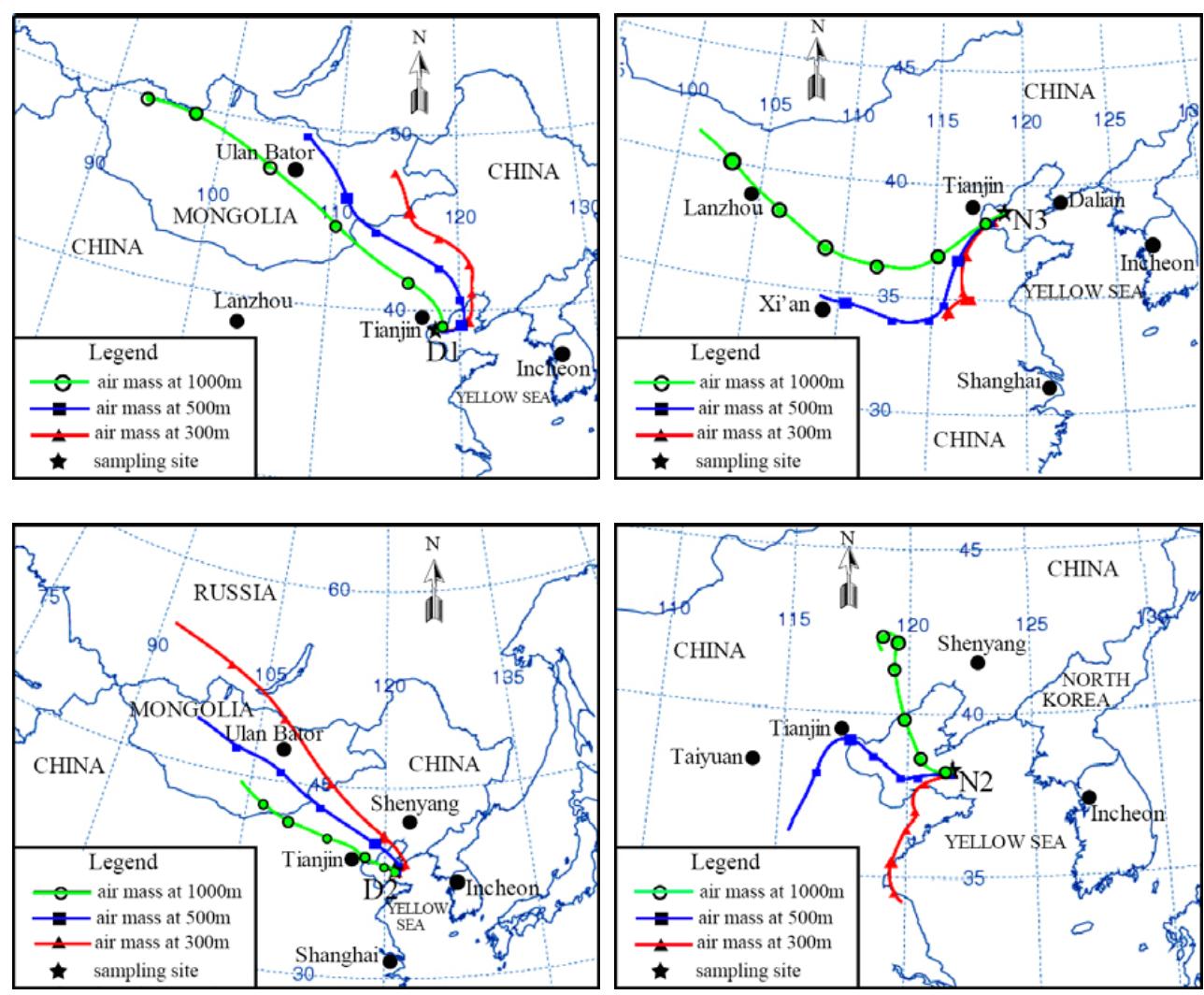

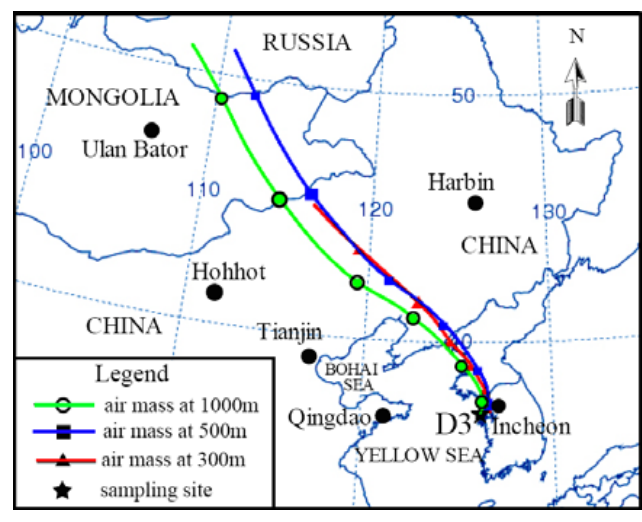

(a) "Asian dust" samples

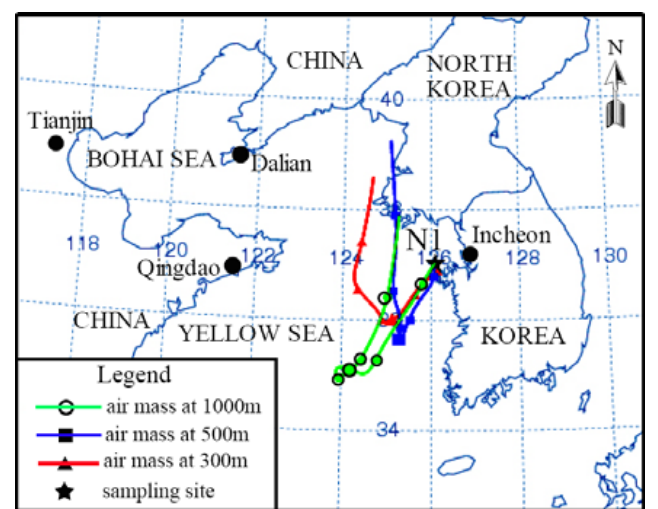

(b) "Non-Asian dust" samples

Fig. 3. $36 \mathrm{~h}$ backward air mass trajectories for different samples. The backward air mass trajectories were calculated via the HYbrid Single Particle Lagrangian Integrated Trajectory (HYSPLIT) model at the NOAA Air Resources Laboratory's web server (http://www.arl.noaa.gov/ ready/hysplit4.html).

$\mathrm{CaSO}_{4}, \mathrm{Ca}\left(\mathrm{NO}_{3}\right)_{2}$, or their mixture compounds, e.g. particles \#20, \#26, \#36, \#42, \#70, and \#77 in Fig. 4.

For $\mathrm{SiO}_{2}$ and $\mathrm{CaCO}_{3}$ particles, the calculated atomic concentration ratios are $[\mathrm{Si}]:[\mathrm{O}] \approx 1: 2$ and $[\mathrm{Ca}]:[\mathrm{C}]:[\mathrm{O}] \approx 1: 1: 3$, very close to their respective stoichiometry (Table 2), indicating the validity of the quantification procedure applied in this study. As far as aluminosilicates, they have many kinds of groups (such as feldspar, mica, kaoline, zeolites, or other minerals containing $\mathrm{Al}$ and $\mathrm{Si}$ ) that accommodate a wide va- riety of cations, such as $\mathrm{Na}^{+}, \mathrm{K}^{+}, \mathrm{Ca}^{2+}, \mathrm{Mg}^{2+}$, and $\mathrm{Fe}^{2+}$, and thus the atomic concentration ratios of $\mathrm{O}, \mathrm{Si}$, and $\mathrm{Al}$ are not constant. The ratios of $[\mathrm{Si}] /[\mathrm{Al}]$ and $[\mathrm{Si}+\mathrm{Al}] /[\mathrm{O}]$ are shown in Table 3. It was found that the ratio of $[\mathrm{Si}+\mathrm{Al}] /[\mathrm{O}]$ in $\mathrm{PM}_{1.0-2.5}$ fraction of Asian dust particles was significantly lower than those in $\mathrm{PM}_{2.5-10}$ fraction of Asian dust and NAD particles while the ratio of $[\mathrm{Si}] /[\mathrm{Al}]$ had no statistically significant difference between the Asian dust and NAD particles, indicating that there were elevated oxygen contents 


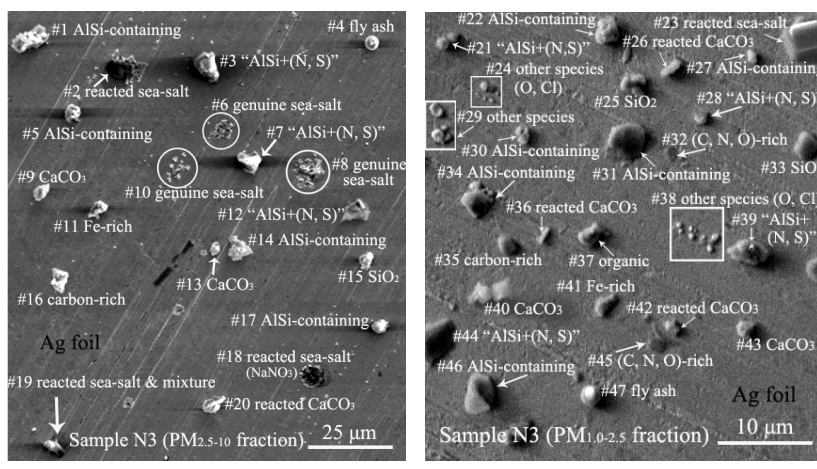

(a) Typical $\mathrm{PM}_{2.5-10}$ and $\mathrm{PM}_{1.0-2.5}$ particles for a non-Asian dust sample
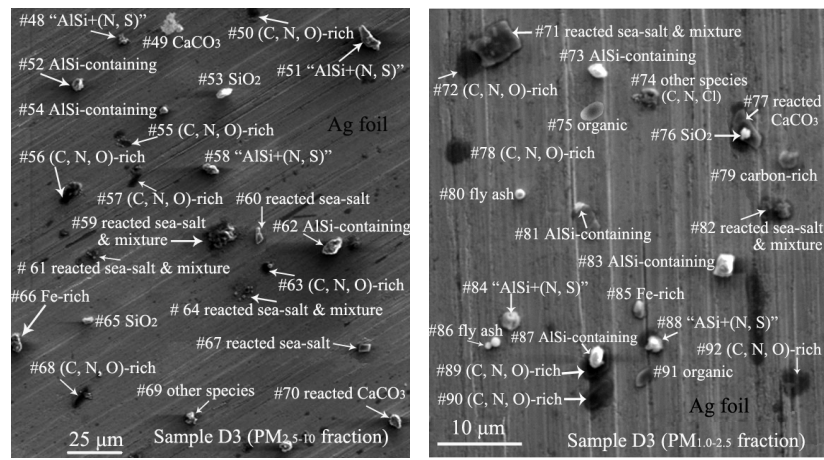

(b) Typical $\mathrm{PM}_{2.5-10}$ and $\mathrm{PM}_{1.0-2.5}$ particles for an Asian dust sample

Fig. 4. Typical particle types for non-Asian dust and Asian dust samples. (Fourteen types of particles are listed here, although the droplet particle rich in $(\mathrm{C}, \mathrm{N}, \mathrm{O}, \mathrm{S})$ is not shown. The elemental concentration data for each particle is shown in Table 2. $(\mathrm{N}, \mathrm{S})$ notation represents the compounds containing either nitrates, sulphates, or both.)

in smaller AlSi-containing particles for Asian dust samples, possibly attributable to their reactions with air pollutants (e.g. $\mathrm{SO}_{2}, \mathrm{NO}_{\mathrm{x}}$ ).

\section{(2) Genuine and reacted sea-salt particles}

The sea is also a major source of primary particles. Sea salt aerosols (SSA) mainly produced by wave action are ubiquitous in the MBL and can significantly impact particulate matter concentrations in coastal regions (Oum et al., 1998; Athanasopoulou et al., 2008). The genuine sea salt particles, e.g. particles \#6, \#8, and \#10 in Fig. 4, are regarded to be generated from the fresh marine-derived particles without experiencing chemical reactions after being emitted into the air by the bursting of air bubbles entrained in breaking waves (i.e., bubble bursting or sea spray process) (de Hoog et al., 2005). Genuine sea salt particles can react with nitrogen and sulfur oxides species in the atmosphere to form reacted (or aged) sea salts, resulting in chlorine loss (sometimes without remaining chloride if they are completely reacted) (McInnes et al., 1994; Gard et al., 1998; Laskin et al.,
2003), e.g. particles \#2,\#18, \#60, and \#67 in Fig. 4. Often, it was observed that the reacted sea salts were mixed with primary or secondary soil-derived particles (e.g. particles \#19, $\# 59$, \#61, \#64, \#71, and \#82 in Fig. 4). They were formed by two possible mechanisms, i.e., (a) collisions of reacted seasalt and soil-derived particles in the atmosphere (Andreae et al., 1986); (b) in-cloud processes through droplet coalescence (Fan et al., 1996). These particles were classified into the group of "reacted sea salts \& mixture," which possibly included components such as $\mathrm{NaCl}, \mathrm{NaNO}_{3}, \mathrm{Na}_{2} \mathrm{SO}_{4}$, $\mathrm{MgSO}_{4}, \mathrm{MgCl}_{2}$, and $\mathrm{Mg}\left(\mathrm{NO}_{3}\right)_{2}$, with minor inclusions of aluminosilicate, $\mathrm{CaSO}_{4}$, or $\mathrm{Ca}\left(\mathrm{NO}_{3}\right)_{2}$. A substantial portion of sea salt particles were collected as water droplets which can be inferred from the morphology. Some sea salt particles appear as a group of particles scattered over a circular dark pattern, e.g. the genuine sea salt particles such as particles \#6, \#8, \#10 and reacted sea salt (\& mixture) particles such as particles \#2,\#18, \#59, \#61, \#64 in Fig. 4. These sea salt particles were possibly collected as a fresh droplet from sea spray, spread over the collecting substrate, and dried out into small crystalline particles. Some sea salt particles have typical cubic shape of sea salts, e.g., the reacted sea salt (\& mixture) particles \#23, \#67, and \#71 in Fig. 4, indicating that these particles were likely collected as single particles and the crystalline shape was well preserved.

It is worth noting that the majority of genuine sea salt particles contained some oxygen that perhaps came from the $\mathrm{NaOH}$ shell around the $\mathrm{NaCl}$ (Laskin et al., 2003). Since $\mathrm{NaOH}$ is very hygroscopic, the sea salt particles will form an alkaline hygroscopic coating that has liquid-like properties as they dry out. $\mathrm{NaOH}$ is generated at the air-solution interface by photolysis of $\mathrm{O}_{3}$, followed by its reaction with water vapor. The surface reaction of ozone is expressed as the following equation (Oum et al., 1998):

$\mathrm{O}_{3}+\mathrm{H}_{2} \mathrm{O}+2 \mathrm{Cl}^{-} \rightarrow \mathrm{Cl}_{2}+2 \mathrm{OH}^{-}+\mathrm{O}_{2}$

\section{(3) Carbonaceous particles}

The carbonaceous particles are divided into two types based on SEI and the contents of $\mathrm{C}, \mathrm{N}$, and $\mathrm{O}$. One is carbon-rich particles, which are defined as those particles wherein the $\mathrm{C}$ and $\mathrm{O}$ atomic concentrations are more than $90 \%$ and the content of $\mathrm{C}$ is 3 times larger than that of $\mathrm{O}$ (Ro et al., 2000). They have complex morphologies such as fractal-like chain structures (e.g. soot aggregates - one of the most abundant forms in urban aerosols), separate spherules (e.g. tar balls), and irregular-shaped carbons (e.g. char) (Chen et al., 2005a). In the present study, no identifiable, separated particles of soot agglomerate and tar ball were encountered, suggesting that the aerosols in the MBL had quite different characteristics from those in an urban environment. Alternatively, it may have been because the soot and tar balls were normally below $1 \mu \mathrm{m}$ in diameter so that the Dekati PM10 impactor 
Table 2. Elemental concentrations in atomic fraction (at. \%) for corresponding particles (samples N3 and D3) in Fig. 4.

\begin{tabular}{|c|c|}
\hline Type & Elemental atomic concentration (at. \%) \\
\hline \multicolumn{2}{|c|}{ 1. Primary soil-derived particles } \\
\hline $\begin{array}{l}\text { (1) AlSi- } \\
\text { containing }\end{array}$ & $\begin{array}{l}\text { N3: \#1 (C:7.5; O:61.2; Al:8.1; Si:19.5; K:3.5); \#5 (C:9.9; O:54.8; Na:5.2; Mg:2.2; Al:8.0; Si:11.6; K:2.1; } \\
\text { Ti:1.2; Fe:4.9); \#14 (C:7.0; O:55.6; Al:8.5; Si:23.8; K:5.1);\#17 (C:7.0; O:57.7; Na:1.8; Mg:1.5; Al:7.4; } \\
\text { Si:17.2; Ca: 5.9; Fe:1.4); \#22 (O:60.2; Mg:2.7; Al:11.9; Si:19.7; K:2.9; Fe:2.1); \#27 (C:2.9; O:64.0; } \\
\text { Mg:2.3; Al:11.2; Si: 17.2; K:2.5);\#30 (O:52.6; Mg:4.5; Al:16.1; Si:22.5; Fe:4.3); \#31 (C:5.3; O:57.6; } \\
\text { Al:13.7; Si:20.3; Ca:1.1; Ti: 1.3); \#34 (C:18.3; O:54.3; Mg:1.6; Al:6.9; Si:10.3; K:1.3; Ca:5.9); \#46 } \\
\text { (C:15.7; O:50.2; Al:11.8; Si:20.6) } \\
\text { D3: \#52 (C:9.7; O:53.6; Na:3.2; Al:8.8; Si:16.5; Ca:3.0; K:2.2; Fe:2.4); \#54 (C:1.8; O:61.7; Na:5.1; } \\
\text { Al:9.2; Si:21.3); \#62 (C:5.7; O:63.7; Al:10.7; Si:15.5; K:2.8); \#73 (C:1.2; O:53.6; Mg:2.4; Al:13.2; } \\
\text { Si:22.0; Ca:7.3);\#81 (C:7.4; O:57.7; Na:2.9; Mg:1.7; Al:8.9; Si:15.1; Ca:5.9);\#83 (C:8.8; O:60.0; } \\
\text { Mg:2.6; Al:8.8; Si:14.1 Ca:4.1);\#87 (O:66.5; Al:8.5; Si:22.3; K:2.6) }\end{array}$ \\
\hline (2) $\mathrm{SiO}_{2}$ & $\begin{array}{l}\text { N3: \#15 (C:6.6; O:62.4; Si:30.0); \#25 (C:3.1; O:66.0; Si:30.0); \#33 (C:7.0; O:61.9; Si:29.8); } \\
\text { D3: \#53 (C:2.3; O:66.7; Si:31.0); \#65 (C:1.4; O:65.1; Si:33.4); \#76 (C:4.0; O:64.3; Si:31.5) }\end{array}$ \\
\hline $\begin{array}{l}(3) \mathrm{CaCO}_{3} \text { or } \\
(\mathrm{Ca}, \mathrm{Mg}) \mathrm{CO}_{3}\end{array}$ & $\begin{array}{l}\text { N3: \#9 (C:21.7; O:48.7; Mg:4.7; Si:1.0; Ca:20.5); \#13 (C:17.1; O:58.0; Mg:1.1; Ca:20.4); \#40 (C:19.8; } \\
\text { O:60.1; Ca:20.0);\#43 (C:17.4; O:59.8; Mg:1.4; Al:1.7; Si:2.8;Ca:16.8) } \\
\text { D3: \#49 (C:19.1; O:61.6; Ca:18.5) }\end{array}$ \\
\hline \multicolumn{2}{|c|}{ 2. Secondary soil-derived particles } \\
\hline (1) $\mathrm{AlSi}+(\mathrm{N}, \mathrm{S})$ & $\begin{array}{l}\text { N3: \#3 (C:4.1; N:7.1; O:53.6; Na:5.9; Mg:3.5; Al:6.8; Si:12.5; K:2.1; Fe:3.7); \#7 (C:2.5; N:7.2; O:51.2; } \\
\text { Na:4.3; Mg:3.0; Al:7.7; Si:17.9; Fe:1.8); \#12 (C:11.9; N:3.7; O:49.4; Na:2.7; Mg:3.1; Al:8.8; Si:18.9; } \\
\text { Fe:1.1); \#21 (C:4.7; N:4.9; O:65.1; Mg:1.5; Al:5.0; Si:14.2; S:2.0; Ca:2.1); \#28 (C:13.1; N:6.6; O:52.4; } \\
\text { F:2.4; Mg:3.7; Al: 5.8; Si:11.8; Cl:1.0; K:1.4; Ca:1.3);\#39 (C:6.0; N:3.4; O:64.9; Na:1.2; Mg:2.8; Al:4.9; } \\
\text { Si:9.5; S:3.4; Ca:3.9); \#44 (N:3.7; O:64.3; Na:2.1; Mg:10.2; Al:5.2; Si:14.2) } \\
\text { D3: \#48 (C:6.0; N:4.7; O:62.9; Na:1.7; Al:8.1; Si:11.1; S:3.9; Ca:1.4);\#51 (C:6.7; N:5.4; O:57.1; Mg:1.7; } \\
\text { Al: 9.5; Si:15.7; K:1.1; Fe:1.8);\#58 (C:11.9; N:7.1; O:54.3; Na:2.8; Mg:2.1; Al:6.6; Si:14.0);\#84 (C:8.1; } \\
\text { N:4.3; O:56.5; Al:8.3; Si:19.2; K:1.0; Ti:1.0);\#88 (C:8.0; N:5.0; O:55.5; Mg:1.7; Al:9.0; Si:17.0; K:2.2; } \\
\text { Fe:1.1) }\end{array}$ \\
\hline $\begin{array}{l}(2) \text { reacted } \\
\mathrm{CaCO} \text { or } \\
(\mathrm{Ca}, \mathrm{Mg}) \mathrm{CO}_{3}\end{array}$ & $\begin{array}{l}\text { N3: \#20 (C:20.3; N:2.9; O:46.8; Na:3.7; Mg:2.5; S:4.2; Ca:19.0); \#26 (C:13.0; N:4.5; O:65.3; Mg:1.8; } \\
\text { S:2.2; Ca:12.7); \#36 (C:5.6; O:67.1; Si:1.4; S:9.2; Cl:1.2; Ca:14.5); \#42 (C:4.2; N:4.6; O:63.5; Al:1.6; } \\
\text { Si:1.8; S:7.9; Ca:15.7) } \\
\text { D3: \#70 (C:9.7; N:4.7; O:59.9; Mg:2.2; S:9.1; Ca:14.3); \#77 (C:21.3; N:5.3; O:47.8; Na:3.7; Mg:2.5; } \\
\text { S:4.2; Ca:15.0) }\end{array}$ \\
\hline \multicolumn{2}{|c|}{ 3. Marine-derived particles } \\
\hline $\begin{array}{l}\text { (1) genuine sea } \\
\text { salt }\end{array}$ & $\begin{array}{l}\text { N3: \#6 (O:11.9; Na:45.3; Mg:4.3; Cl:38.5); \#8 (C:1.8; O:6.9; Na:37.8; Mg:10.8; Cl:42.6); \#10 (C:1.8; } \\
\text { O:36.9; Na:27.8; Mg:10.8; Cl:22.6) }\end{array}$ \\
\hline (2) reacted sea salt & $\begin{array}{l}\text { N3: \#2 (N:18.5; O:50.3; Na:22.8; Mg:1.3; S:3.8; Cl:3.1); \#18 (N:19.5; O:58.4; Na:20.1; Mg:1.9); \#23 } \\
\text { (N:18.8; O:59.3; Na:20.2; S:1.7) } \\
\text { D3: \#60 (C:1.4; N:18.8; O:59.5; Na:19.6); \#67 (N:18.1; O:57.6; Na:19.0; Mg:5.2) }\end{array}$ \\
\hline $\begin{array}{l}\text { (3) reacted sea salt } \\
\& \text { mixture }\end{array}$ & $\begin{array}{l}\text { N3: \#19 (O:58.8; Na:15.3; S:11.7; Cl:3.7; Ca:9.9) } \\
\text { D3: \#59 (C:14.9; N:13.4; O:37.4; Na:13.5; Cl:4.9; Ca: 12.2); \#61 (C:9.2; N:4.9; O:46.3; Na:20.2; S:2.4; } \\
\text { Cl:7.1; Ca:4.7); \#64 (C:6.6; N:3.8; O:51.5; Na:13.7; S:1.1; Cl:11.5; Ca:11.7); \#71 (C:8.8; N:6.9; O:53.7; } \\
\text { Na:12.8; Mg:1.8; S:3.9; Ca: 12.0); \#82 (C:11.1; N:7.7; O:61.8; Na:7.3; Al:1.2; Si:2.4; S:3.7; Cl:1.0; } \\
\text { Ca:3.8) }\end{array}$ \\
\hline \multicolumn{2}{|c|}{ 4. carbonaceous particles } \\
\hline (1) carbon-rich & $\begin{array}{l}\text { N3: \#16 (C:83.1; O:16.9); \#35 (C:86.8; O:12.7) } \\
\text { D3: \#79 (C:93.0; O:7.0) }\end{array}$ \\
\hline $\begin{array}{l}\text { (2) organic parti- } \\
\text { cles }\end{array}$ & $\begin{array}{l}\text { N3: \#37 (C:49.4; N:2.9; O:43.4; Na:1.3; Mg:1.4); } \\
\text { D3: \#75 (C:37.7; N:9.1; O:43.8; P:2.3; K:2.1; Ca:1.0); \#91 (C:64.1; O:35.9) }\end{array}$ \\
\hline $\begin{array}{l}\text { 5. droplet rich in } \\
(\mathrm{C}, \mathrm{N}, \mathrm{O})\end{array}$ & $\begin{array}{l}\text { N3: \#32 (C:18.6; N:22.7; O:53.0; Mg:5.1); \#45 (C:16.9; N:24.8; O:51.6; Mg:5.8) } \\
\text { D3: \#50 (C:32.0; N:33.6; O:29.9; Mg:3.4); \#55 (C:34.0; N:25.6; O:35.1; Mg:5.3); \#56 (C:31.6; N:34.3; } \\
\text { O:28.1; Mg:5.9); \#57 (C:32.7; N:33.1; O:28.6; Mg:5.6); \#63 (C:23.4; N:30.5; O:39.9; Na:1.6; Mg:4.6); } \\
\text { \#68 (C:33.2; N:29.2; O:28.7; Na:2.0; Mg:5.9); \#72 (C:22.2; N:23.8; O:48.8; Na:1.3; Mg:3.1); \#78 } \\
\text { (C:22.8; N:23.8; O:48.7; Mg:3.8);\#89 (C:19.4; N:32.6; O:41.8; Mg:5.2); \#90 (C:22.1; N:29.4; O:41.9; } \\
\text { Na:2.8; Mg:3.8);\#92 (C:22.1; N:25.0; O:49.2; Mg:3.7) }\end{array}$ \\
\hline $\begin{array}{l}\text { 6. Fe-rich } \\
\text { particles }\end{array}$ & $\begin{array}{l}\text { N3: \#11 (C:2.2; O:69.3; Na:1.0; Mg:1.4; Al:1.0; Si:2.8; Fe:22.2); \#41 (C:1.5; O:64.5; Fe:34.0) } \\
\text { D3: \#66 (C:8.5; O:54.5; S:6.5; Ca:5.7; Fe:23.5); \#85 (O:56.2; Fe:43.8) }\end{array}$ \\
\hline 7. fly ash & $\begin{array}{l}\text { N3: \#4 (C:2.8; O:63.4; Si:1.8; Ti:12.4; Mn:4.0; Fe:12.2);\#47 (C:3.6; O:62.0; Fe:34.4) } \\
\text { D3: \#80 (C:1.4; O:65.5; Al:15.2; Si:15.4; Fe:2.5); \#86 (C:2.1; O:61.9; Na:1.4; Mg:1.0; Al:12.1; Si:19.4) }\end{array}$ \\
\hline $\begin{array}{l}\text { 8. other } \\
\text { species }\end{array}$ & $\begin{array}{l}\text { N3: \#24 (O:21.7; Cl:78.3); \#29 (O:19.8; Na:4.4; Cl:75.8); \#38 (O:11.3; Cl:88.7) } \\
\text { D3: \#69 (C:7.8; O:62.8; Cl:1.3; Ti:27.1) (TiO }) \text {; \#74 (C:46.9; N:29.8; Cl:23.3) }\end{array}$ \\
\hline
\end{tabular}

Note: (1) Particle classification was based both on SEI and element contents from X-ray data. Elements with atomic concentration less than $1.0 \%$ were neglected.

(2) $(\mathrm{N}, \mathrm{S})$ notation represents the compounds containing nitrates, sulfates, or both. 
Table 3. Atomic concentration ratios of $\mathrm{Al} / \mathrm{Si}$ and $(\mathrm{Al}+\mathrm{Si}) / \mathrm{O}$ in $\mathrm{AlSi}$-containing particles (including aluminosilicate and "aluminosilicate $+(\mathrm{N}, \mathrm{S})$ " particles).

\begin{tabular}{lllll}
\hline Particles & \multicolumn{2}{c}{ Ratio of $[\mathrm{Al}] /[\mathrm{Si}]$} & \multicolumn{2}{c}{ Ratio of [Al+Si]/[O] } \\
\hline & $\mathrm{PM}_{2.5-10}$ & $\mathrm{PM}_{1.0-2.5}$ & $\mathrm{PM}_{2.5-10}$ & $\mathrm{PM}_{1.0-2.5}$ \\
\hline $\begin{array}{l}\text { Non-Asian dust } \\
\text { samples }\end{array}$ & $\begin{array}{l}0.534 \pm 0.188 \\
(n=211)\end{array}$ & $\begin{array}{l}0.556 \pm 0.183 \\
(n=225)\end{array}$ & $\begin{array}{l}0.428 \pm 0.188 \\
(n=211)\end{array}$ & $\begin{array}{l}0.396 \pm 0.152 \\
(n=225)\end{array}$ \\
$\begin{array}{l}\text { N3, N2, N1) } \\
\begin{array}{l}\text { Asian dust samples } \\
(\mathrm{D} 1, \mathrm{D} 2, \mathrm{D} 3)\end{array}\end{array}$ & $\begin{array}{l}0.520 \pm 0.182 \\
(n=246)\end{array}$ & $\begin{array}{l}0.542 \pm 0.184 \\
(n=214)\end{array}$ & $\begin{array}{l}0.453 \pm 0.151 \\
(n=246)\end{array}$ & $\begin{array}{l}0.333 \pm 0.142^{\# *} \\
(n=214)\end{array}$ \\
\hline
\end{tabular}

Note: (1) The results are expressed as mean \pm sd. " $n$ " represents the number of particles.

(2) Comparison between particle size (\#: $p \leq 0.05)$ and between samples $(*: p \leq 0.05)$ was tested by two-way ANOVA. There is statistical significance when $p$ value $\leq 0.05$.

failed to collect them. It was reported that a large number of small secondary aerosol particles (aerodynamic diameter $<1 \mu \mathrm{m}$ ) in ambient aerosol samples were soot inclusions and about $90 \%$ of the soot inclusions had a size of $20-250 \mathrm{~nm}$ (Vester et al., 2007). Only a handful of char particles were observed (11 of 900 in $\mathrm{PM}_{2.5-10}$ fraction and 3 of 900 in $\mathrm{PM}_{1.0-2.5}$ fraction), e.g. particles \#16, \#35, and \#79 in Fig. 4. They were probably derived from the pyrolysis and oxidation of fuel particles, and had compact and irregular-shaped morphologies that were related to the nature of the fuel, the fuel/air ratio, and the combustion temperature (Chen et al., 2005a, b).

The second type of carbonaceous particles is organic carbons, which have high $\mathrm{C}$ and $\mathrm{O}$ contents, sometimes with minor $\mathrm{N}, \mathrm{P}, \mathrm{S}, \mathrm{K}$ and/or $\mathrm{Cl}$, e.g. particles \#37, \#75, and \#91 in Fig. 4. They are mostly from combustion or of biogenic origins (Jurado et al., 2008). The simultaneous presence of minor $\mathrm{N}, \mathrm{K}, \mathrm{P}, \mathrm{S}$, and/or $\mathrm{Cl}$ with $\mathrm{C}$ and $\mathrm{O}$ is considered to be a "biogenic fingerprint" (Ro et al., 2002), e.g. particle \#75. Relatively few biogenic particles were encountered in the collected samples. It is likely that the majority of organic compounds came from the products of combustion (resulting from biomass burning, automotive or industrial sources) in the surrounding area, or resulted from the oxidation of volatile organic compounds (Jurado et al., 2008). Besides, crude oils spilled on the surface of the sea from tanker ships or cargo vessels could not be excluded (Wang et al., 2008).

\section{(4) Droplet particles rich in $(\mathrm{C}, \mathrm{N}, \mathrm{O})$ and $(\mathrm{C}, \mathrm{N}, \mathrm{O}, \mathrm{S})$}

Two types of droplet particles have to be paid particular attention. One is rich in $(\mathrm{C}, \mathrm{N}, \mathrm{O})$ and the other is rich in (C, N, O, S). They have similar morphology (dark shades) in the SEI due to low secondary and backscattered electron yields. The droplet particles rich in $(\mathrm{C}, \mathrm{N}, \mathrm{O})$, likely the mixture of organic matter and $\mathrm{NH}_{4} \mathrm{NO}_{3}$, often include minor (less than 6 at.\%) $\mathrm{Na}$ and $\mathrm{Mg}$ that possibly come from seawater, but without $\mathrm{S}$, e.g. particles \#32, \#45, \#50, \#55, $\# 56$, \#57, \#63, \#68, \#72, \#78, \#89, \#90, and \#92 in Fig. 4 and Table 2 . They are abundant in nearly all the samples. However, the droplet particles rich in $(\mathrm{C}, \mathrm{N}, \mathrm{O}, \mathrm{S})$, which seem to be a mixture of organic matter and $\mathrm{NH}_{4} \mathrm{HSO}_{4} /\left(\mathrm{NH}_{4}\right)_{2} \mathrm{SO}_{4}$ (also sometimes with minor $\mathrm{Na}$ and $\mathrm{Mg}$ ), were observed only in $\mathrm{PM}_{1.0-2.5}$ fraction of samples $\mathrm{N} 1$ and N2. Since $\mathrm{NH}_{4} \mathrm{NO}_{3}$ and $\mathrm{NH}_{4} \mathrm{HSO}_{4} /\left(\mathrm{NH}_{4}\right)_{2} \mathrm{SO}_{4}$ are hygroscopic, they can be readily mixed with seawater droplets containing $\mathrm{Na}$ and $\mathrm{Mg}$ in the MBL, making the particles become droplets. The reaction of $\mathrm{NH}_{3}$ with $\mathrm{HNO}_{3}$ produces $\mathrm{NH}_{4} \mathrm{NO}_{3}$ particles with $\mathrm{D}_{p}<1 \mu \mathrm{m}$, and the thermodynamic equilibrium between $\mathrm{HNO}_{3}$ and $\mathrm{NH}_{4} \mathrm{NO}_{3}$ strongly depends on ambient temperature and relative humidity (Miyazaki et al., 2005). However, the $(\mathrm{C}, \mathrm{N}, \mathrm{O})$-rich droplet particles observed in the present study often had sizes larger than $1 \mu \mathrm{m}$, suggesting that the relative humidity in the ambient air was relatively high, causing the particles to be collected as droplets.

Carbon-rich or organic matter contained in these particles likely originated from crude oils spilled on the surface of the sea, marine organisms, or the "humic-like substances (HULIS)" in seawater. HULIS, which mostly come from biomass burning or are of biogenic origin, have high contents of carbon and oxygen (Krivacsy et al., 2008). Vester et al. (2007) reported that the significant fraction of aerosol particles in the size range of $0.1-10 \mu \mathrm{m}$ aerodynamic diameter collected at an urban background station in Germany is composed of secondary aerosol particles in droplet shape mainly containing ammonium, nitrate, sulfate, and organics. The droplet particles rich in $(\mathrm{C}, \mathrm{N}, \mathrm{O})$ or $(\mathrm{C}, \mathrm{N}, \mathrm{O}, \mathrm{S})$ that we observed here are likely a part of the complex secondary aerosol particles as they reported.

\section{(5) Fe-rich, fly ash, and other species particles}

Fe-rich particles have irregular shapes on the SEI and usually contain more than 20 at.\% of Fe element species, e.g. 
particles \#11, \#41, \#66, and \#85 in Fig. 4 and Table 2. Their major type is iron oxide/hydroxides, the main sources of which are metallurgical processes, traffic, and coal combustion (Ro et al., 2002). These Fe-rich particles possibly come from the surrounding cities and steel factories near the coast.

Fly ash is a powdery material made up of tiny glass spheres that consists primarily of silicon, aluminum, iron, and/or calcium oxides. It is formed by mineral transformation in hightemperature combustion processes and has longer residence periods in the atmosphere. The fly ash particle tends to be small and spherical, has a bright and circular shape on SEI images, and is easily distinguished, e.g. particles \#4, \#47, $\# 80$, and \#86 in Fig. 4. Large quantities of fly ash are generated by coal combustion for electric utilities and power plants (Chen et al., 2004).

The particles that could not be classified into any of the above fourteen types were put in the category of "other species." They included $\mathrm{TiO}_{\mathrm{x}}, \mathrm{CuO}_{\mathrm{x}}, \mathrm{MgO}$, and $(\mathrm{O}, \mathrm{Cl})$ - and $(\mathrm{C}, \mathrm{N}, \mathrm{Cl})$-rich particles with low encounter frequencies, e.g. particles \#24, \#29, \#38, \#69 and \#74 in Fig. 4. It is possible that the particle rich in $(\mathrm{O}, \mathrm{Cl})$ is $\mathrm{AgCl}$ or $\mathrm{AgO}$ in which $\mathrm{Ag}^{+}$failed to be distinguished due to the disturbance of the substrate. The particle rich in $(\mathrm{C}, \mathrm{N}, \mathrm{Cl})$ is the mixture of organic matter and $\mathrm{NH}_{4} \mathrm{Cl}$, which is probably the reaction product of $\mathrm{NH}_{3}$ with $\mathrm{HCl}$. The major sources of $\mathrm{NH}_{3}$ are animal waste, fertilizer, soil emissions, and industrial emissions (Sorooshian et al., 2008), and $\mathrm{HCl}$ is likely a result of the reaction of $\mathrm{NaCl}$ from sea salts with $\mathrm{HNO}_{3}\left(\right.$ or $\mathrm{H}_{2} \mathrm{SO}_{4}$ ) (Sullivan et al., 2007).

\subsection{Effects of an Asian dust storm event on particle abundances}

\subsubsection{Effects on relative abundance of soil-derived par- ticles}

As shown in Table 4, the primary soil-derived particles in which AlSi-containing particles greatly outnumber $\mathrm{SiO}_{2}$ and $\mathrm{CaCO}_{3}$ have higher relative abundance in $\mathrm{PM}_{2.5-10}$ fraction than in $\mathrm{PM}_{1.0-2.5}$ fraction (on average, $43.8 \%$ vs. $14.0 \%$ for Asian dust samples, and $46.9 \%$ vs. $26.2 \%$ for NAD samples), in contrast to the secondary soil-derived particles (24.2\% in $\mathrm{PM}_{2.5-10}$ fraction vs. $46.9 \%$ in $\mathrm{PM}_{1.0-2.5}$ fraction for Asian dust samples, and $19.2 \%$ vs. $37.3 \%$ for NAD samples), indicating that the fine soil-derived particles in the atmosphere are more prone to reacting or mixing with air pollutants or "secondary acids" than are the coarse ones, which agrees with the results from Table 3. Along the Bohai Bay, the Bohai Straits, and Yellow Sea, the relative abundances of primary soil-derived particles in both $\mathrm{PM}_{2.5-10}$ and $\mathrm{PM}_{1.0-2.5}$ fractions gradually decrease, suggesting the presence of a deposition or composition-modifying process affecting these particles during transport. Based on the observation that the relative abundances of secondary soil-derived particles for Asian dust samples on the Yellow Sea (D3: 30.0\% in

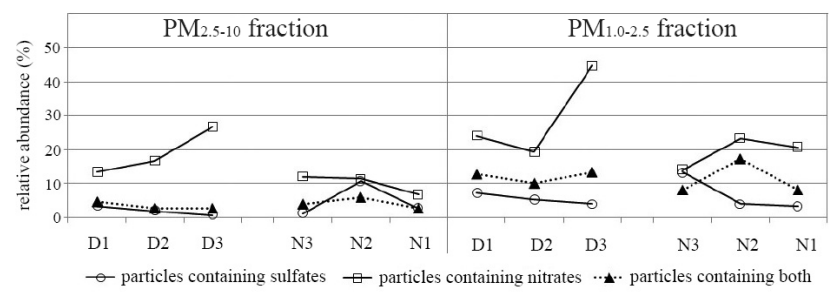

(a) Secondary soil-derived particles

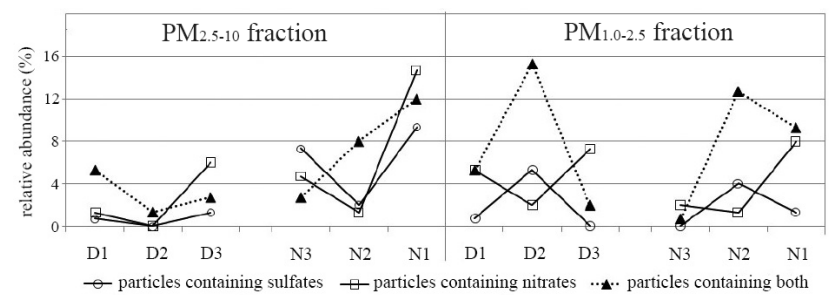

(b) Reacted sea salt (\& mixture) particles

Fig. 5. Relative abundances of secondary soil- or marine-derived particles containing nitrates, sulfates, or both. (The secondary soilderived particles included "aluminosilicates $+(\mathrm{N}, \mathrm{S})$ " and "reacted $\mathrm{CaCO}_{3} /(\mathrm{Ca}, \mathrm{Mg}) \mathrm{CO}_{3}$ "; and the secondary marine-derived particles included "reacted sea salts" and "reacted sea salts \& mixture".)

$\mathrm{PM}_{2.5-10}$ and $62.0 \%$ in $\mathrm{PM}_{1.0-2.5}$ fraction) outweigh those for NAD samples (N1: $12.0 \%$ in $\mathrm{PM}_{2.5-10}$ and $32.0 \%$ in $\mathrm{PM}_{1.0-2.5}$ fraction), the Asian dust storm event seems to increase secondary soil-derived particles in the MBL of the Yellow Sea. The possible reasons are: on one hand, anthropogenic $\mathrm{SO}_{2}$ and $\mathrm{NO}_{\mathrm{x}}$ in the MBL of the Yellow Sea are abundant, providing more chances for these chemicals to react with the mineral dust; on the other hand, air masses passing over northeast China (Fig. 3) carry mineral dusts that have already reacted with "secondary acids," since a large amount of $\mathrm{SO}_{2}$ and $\mathrm{NO}_{\mathrm{x}}$ are emitted in that region (Hatakeyama et al., 2005).

Nitrogen-containing particles provide essential nutrients for ocean life through wet and dry atmospheric depositions (Zhang et al., 2007). However, excessive supply of nitrogen nutrition (e.g., the atmospheric deposition of organic nitrogen, ammonium, and nitrate) leads to eutrophication in the oceanic, coastal, and shelf regions (Bergstrom and Jansson, 2006). Fig. 5a shows that in nearly all the samples, the secondary soil-derived particles containing nitrates are the most frequently encountered, followed by those containing both nitrates and sulfates, and then those containing sulfates. This suggests that a large amount of nitrogen-containing particles are deposited into the Bohai Sea and Yellow Sea.

It was reported that Asian dust storm events provide a removal mechanism for $\mathrm{NO}_{\mathrm{x}}$ (or $\mathrm{HNO}_{3}$ ) and perhaps contribute to nitrogen deposition in the Yellow Sea (Wu and Okada, 1994). In the present work, the amount of nitratecontaining, soil-derived particles is found to be higher in the Asian dust samples than in the NAD samples. Moreover, 
Table 4. Particle types and their relative abundances in non-Asian dust (NAD) and Asian dust samples.

\begin{tabular}{|c|c|c|c|c|c|c|c|c|c|c|c|c|c|c|c|c|}
\hline \multirow[t]{3}{*}{ Types } & \multicolumn{8}{|c|}{ relative abundance in $\mathrm{PM}_{2.5-10}$ fraction (\%) } & \multicolumn{8}{|c|}{ relative abundance in $\mathrm{PM}_{1.0-2.5}$ fraction (\%) } \\
\hline & \multicolumn{4}{|c|}{ Asian dust samples } & \multicolumn{4}{|c|}{ NAD samples } & \multicolumn{4}{|c|}{ Asian dust samples } & \multicolumn{4}{|c|}{ NAD samples } \\
\hline & D1 & D2 & D3 & ave & N3 & N2 & N1 & ave & D1 & D2 & D3 & ave & N3 & $\mathrm{N} 2$ & N1 & ave \\
\hline 1. Primary soil-derived particles & 57.3 & 54.0 & 20.0 & 43.8 & 58.7 & 50.7 & 31.3 & 46.9 & 18.0 & 21.3 & 2.7 & 14.0 & 48.7 & 16.7 & 13.3 & 26.2 \\
\hline (1) AlSi-containing & 45.3 & 46.7 & 13.3 & 35.1 & 36.7 & 34.7 & 25.3 & 32.2 & 12.0 & 18.7 & 1.3 & 10.7 & 39.3 & 12.0 & 12.0 & 21.1 \\
\hline (2) $\mathrm{SiO}_{2}$-containing & 9.3 & 5.3 & 6.0 & 6.9 & 8.7 & 9.3 & 3.3 & 7.1 & 3.3 & 2.7 & 1.3 & 2.4 & 4.0 & 3.3 & 1.3 & 2.9 \\
\hline (3) $\mathrm{CaCO}_{3}$ or $(\mathrm{Ca}, \mathrm{Mg}) \mathrm{CO}_{3}$ & 2.7 & 2.0 & 0.7 & 1.8 & 13.3 & 6.7 & 2.7 & 7.6 & 2.7 & 0 & 0 & 0.9 & 5.3 & 1.4 & 0 & 2.2 \\
\hline 2. Secondary soil-derived particles & 21.3 & 21.3 & 30.0 & 24.2 & 17.3 & 28.0 & 12.0 & 19.2 & 44.0 & 34.7 & 62.0 & 46.9 & 35.3 & 44.7 & 32.0 & 37.3 \\
\hline (1) aluminosilicate $+(\mathrm{N}, \mathrm{S})$ & 15.3 & 16.7 & 30.0 & 20.7 & 15.3 & 22.0 & 9.3 & 15.6 & 28.0 & 32.0 & 54.0 & 38.0 & 26.7 & 32.7 & 30.7 & 30.0 \\
\hline (2) reacted $\mathrm{CaCO}_{3}$ & 6.0 & 4.7 & 0 & 3.6 & 2.0 & 6.0 & 2.7 & 3.6 & 16.0 & 2.7 & 8.0 & 8.9 & 8.7 & 12.0 & 1.3 & 7.3 \\
\hline 3. Marine-derived particles & 7.3 & 2.7 & 10.0 & 6.7 & 16.7 & 11.3 & 38.0 & 22.0 & 11.3 & 22.0 & 9.3 & 14.3 & 2.7 & 18.0 & 18.7 & 13.1 \\
\hline (1) genuine sea salts & 0 & 0.7 & 0 & 0.2 & 2.0 & 0.7 & 4.0 & 2.2 & 0 & 0 & 0 & 0 & 0 & 0 & 0 & 0 \\
\hline (2) reacted sea salts & 4.0 & 1.3 & 4.0 & 3.1 & 10.0 & 5.3 & 26.0 & 13.8 & 5.3 & 14.0 & 6.7 & 8.7 & 2.0 & 7.3 & 11.3 & 6.9 \\
\hline (3) reacted sea salts \& mixture & 3.3 & 0.7 & 6.0 & 3.3 & 4.7 & 6.0 & 8.0 & 6.2 & 6.0 & 8.0 & 2.7 & 5.6 & 0.7 & 10.7 & 7.3 & 6.2 \\
\hline 4. carbonaceous particles & 1.4 & 1.3 & 0.7 & 1.1 & 4.7 & 4.0 & 3.3 & 4.0 & 0 & 2.0 & 0.7 & 0.9 & 4.0 & 4.0 & 5.4 & 4.5 \\
\hline (1) carbon-rich particles & 0.7 & 0 & 0 & 0.2 & 2.7 & 2.7 & 1.3 & 2.2 & 0 & 0 & 0.7 & 0.2 & 0.7 & 0 & 0.7 & 0.5 \\
\hline (2) organic particles & 0.7 & 1.3 & 0.7 & 0.9 & 2.0 & 1.3 & 2.0 & 1.8 & 0 & 2.0 & 0 & 0.7 & 3.3 & 4.0 & 4.7 & 4.0 \\
\hline 5. droplet rich in $(\mathrm{C}, \mathrm{N}, \mathrm{O})$ & 12.7 & 12.0 & 35.3 & 20.0 & 1.3 & 2.0 & 10.0 & 4.4 & 26.0 & 17.3 & 18.0 & 20.4 & 3.3 & 8.7 & 18.7 & 10.2 \\
\hline 6. droplet rich in $(\mathrm{C}, \mathrm{N}, \mathrm{O}, \mathrm{S})$ & 0 & 0 & 0 & 0 & 0 & 0 & 0 & 0 & 0 & 0 & 0 & 0 & 0 & 5.3 & 8.0 & 4.4 \\
\hline 7. Fe-rich particles & 0 & 2.7 & 1.3 & 1.3 & 0.7 & 2.7 & 4.0 & 2.4 & 0.7 & 1.3 & 3.3 & 1.8 & 1.3 & 1.3 & 1.3 & 1.3 \\
\hline 8. fly ash particles & 0 & 0 & 2.0 & 0.7 & 0.7 & 0 & 0.7 & 0.4 & 0 & 0.7 & 3.3 & 1.3 & 0 & 0 & 1.3 & 0.4 \\
\hline 9. other species & 0 & 6.0 & 0.7 & 2.2 & 0 & 1.3 & 0.7 & 0.7 & 0 & 0.7 & 0.7 & 0.4 & 4.7 & 1.3 & 1.3 & 2.4 \\
\hline
\end{tabular}

the amount of such particles increases from the Bohai Sea to the Yellow Sea, peaking at $44.7 \%$ in $\mathrm{PM}_{1.0-2.5}$ fraction and $26.7 \%$ in $\mathrm{PM}_{2.5-10}$ fraction (sample D3), whereas the amount of such particles in the NAD samples tends to decrease (Fig. 5a). The results suggest that airborne $\mathrm{NO}_{\mathrm{x}}$ (or $\mathrm{HNO}_{3}$ ) rather than $\mathrm{SO}_{2}\left(\right.$ or $\left.\mathrm{H}_{2} \mathrm{SO}_{4}\right)$ is prone to react with the primary supermicron alminosilicate, $\mathrm{SiO}_{2}$, and $\mathrm{CaCO}_{3}$ particles; or, the mass concentration of $\mathrm{NO}_{\mathrm{x}}$ in the MBL of the Yellow Sea might be higher than the mass concentration of $\mathrm{SO}_{2}$. In addition, photochemistry, sink processes, and a number of other factors also play important roles in the formation/decomposition process of nitrate- or sulfate-containing particles (Sullivan et al., 2007; Hwang et al., 2006). The decreasing trend for the sulfate-containing secondary soilderived particles both in the Asian dust and in the NAD samples from the Bohai Sea to the Yellow Sea (Fig. 5a) indicates that the impact of $\mathrm{NO}_{\mathrm{x}}$ on soil-derived particles is larger than that of $\mathrm{SO}_{2}$ in the MBL near the Seoul-Incheon metropolis.

\subsubsection{Effects on the relative abundance of marine- derived particles}

The Asian dust storm event reduced relative abundances of coarse sea salt particles. In $\mathrm{PM}_{2.5-10}$ fraction, not only the genuine sea salt particles but also the reacted sea salt ( $\&$ mixture) particles exhibited lower encounter frequencies in the Asian dust samples than in the NAD samples (Table 4). In $\mathrm{PM}_{1.0-2.5}$ fraction, genuine sea salt particles were not observed for either type of sample, and there was no significant difference in the average abundances of reacted sea salt ( \& mixture) particles between the Asian dust and NAD samples. This indicates that the Asian dust storm event had a greater impact on big sea salt particles than on small ones.
Marine particles can react with $\mathrm{SO}_{2}$ and $\mathrm{NO}_{\mathrm{x}}$ to produce $\mathrm{Na}_{2} \mathrm{SO}_{4}$ and $\mathrm{NaNO}_{3}$ particles, respectively (Laskin et al., 2003). In our previous studies, it has been convincingly demonstrated that the low- $Z$ particle EPMA technique can clearly distinguish "genuine" (either in the form of $\mathrm{NaCl}$ or a mixture of $\mathrm{NaCl}$ and $\mathrm{MgCl}_{2}$ ) from "reacted" sea salts (mostly nitrate and/or sulfate of sodium and/or magnesium) (Hwang and Ro, 2006). Herein, the reacted sea salts (\& mixture) were classified into 3 types, i.e. nitrate (N)-containing, sulfate (S)containing, and both nitrate and sulfate $(\mathrm{N}+\mathrm{S})$-containing types. Figure $5 \mathrm{~b}$ shows that the reacted sea salt (\& mixture) particles in $\mathrm{PM}_{1.0-2.5}$ fraction have a similar distribution at the three sampling locations for the Asian dust and NAD particles. Namely, $(\mathrm{N}+\mathrm{S})$ - but (S)-containing particles are more abundant in the samples collected in the Bohai Straits than in those collected on Bohai Bay and the Yellow Sea, which is in contrast to the case for $(\mathrm{N})$-containing particles, which are more abundant in the samples collected on the Bohai Bay and the Yellow Sea. $(\mathrm{N}+\mathrm{S})$-containing particles from the Bohai Straits greatly outnumber $(\mathrm{N})$ - or $(\mathrm{S})$-containing particles from the Bohai Straits. In $\mathrm{PM}_{2.5-10}$ fraction, the relative abundances of $(\mathrm{N}+\mathrm{S})$-containing particles for the Asian dust samples tend to decrease from the Bohai Sea to the Yellow Sea, whereas those for the NAD samples tend to increase, suggesting that the Asian dust storm event reduced the coarse $(\mathrm{N}+\mathrm{S})$-containing sea salts (\& mixture) in the MBL of the Yellow Sea.

On normal (non-Asian dust) days, air pollutants from Eastern China take 1-2 days to arrive at the Korean peninsula (the width of the Yellow Sea between Eastern China and the Korean peninsula is $350 \mathrm{~km}-700 \mathrm{~km}$ ), with the air masses passing through the Yellow Sea. This means that there is enough time for $\mathrm{SO}_{2}$ to be oxidized into $\mathrm{H}_{2} \mathrm{SO}_{4}$ or $\mathrm{SO}_{4}^{2-}$ and 
to interact with sea salt aerosol particles, resulting in the elevation of reacted sea salt ( $\&$ mixture) concentrations in the MBL of the Yellow Sea. However, during the Asian dust storm event, higher wind speeds and lower relative humidity possibly hindered the transformation of $\mathrm{SO}_{2}$ into $\mathrm{H}_{2} \mathrm{SO}_{4}$ or $\mathrm{SO}_{4}^{2-}$, therefore leading to fewer (S)-containing and (N+S)containing particles. In addition, the presence of dimethylsulfide (DMS) in the seawater might complicate the discussion regarding the reaction of sea salt particles with anthropogenic $\mathrm{NO}_{\mathrm{x}}$ and $\mathrm{SO}_{2}$ in the MBL. DMS, which is produced by marine microbiota and is the most abundant volatile sulfur compound emitted into the atmosphere from the ocean, can be oxidized to form various sulfur containing products, such as $\mathrm{SO}_{2}$, methanesulfonic acid (MSA), and non-sea salt $\mathrm{SO}_{4}^{2-}$ (nss-SO ${ }_{4}^{2-}$ ) (Yang et al., 2009). An investigation of the spatial distributions of atmospheric DMS and the sea-to-air flux of DMS in the North Yellow Sea, China, reported the reduction of the concentrations of DMS from inshore to offshore sites in the surface water, revealing the indirect effects of DMS on the aerosol compositions in the MBL (Yang et al., 2009).

\subsubsection{Effects on the relative abundances of droplet par- ticles rich in $(\mathrm{C}, \mathrm{N}, \mathrm{O})$ and $(\mathrm{C}, \mathrm{N}, \mathrm{O}, \mathrm{S})$}

The (C, N, O)-rich droplet particles were frequently encountered both in $\mathrm{PM}_{2.5-10}$ and $\mathrm{PM}_{1.0-2.5}$ fractions, and greatly outnumbered the $(\mathrm{C}, \mathrm{N}, \mathrm{O}, \mathrm{S})$-rich droplet particles that were only encountered in $\mathrm{PM}_{1.0-2.5}$ fraction (Table 4). For the NAD samples, the relative abundances of $(\mathrm{C}, \mathrm{N}, \mathrm{O})$-rich droplets increased from Bohai Bay to the Yellow Sea. This is not unexpected, given that emissions of anthropogenic pollutant precursors are plentiful around the Yellow Sea, and that the relative humidity in the MBL is high, therefore providing favourable conditions for the gas-aerosol interaction and for the nitrate-ammonia interaction to form $\mathrm{NH}_{4} \mathrm{NO}_{3}$ on the aerosol (Pandey et al., 2008).

Moreover, the relative abundances of $(\mathrm{C}, \mathrm{N}, \mathrm{O})$-rich droplets in the Asian dust samples were significantly elevated over those of the NAD samples (on average 20.0\% vs. $4.4 \%$ in $\mathrm{PM}_{2.5-10}$ fraction and $20.4 \%$ vs. $10.2 \%$ in $\mathrm{PM}_{1.0-2.5}$ fraction), suggesting that the $\mathrm{NH}_{4} \mathrm{NO}_{3}$-containing particles increased in number when the Asian dust passed over the MBL. The observation that no $(\mathrm{C}, \mathrm{N}, \mathrm{O}, \mathrm{S})$-rich droplets were encountered in the Asian dust samples implies that the Asian dust storm event reduced the formation of $\mathrm{NH}_{4} \mathrm{HSO}_{4} /\left(\mathrm{NH}_{4}\right)_{2} \mathrm{SO}_{4}$-containing droplets. It is likely that, on one hand, $\mathrm{NH}_{4} \mathrm{HSO}_{4} /\left(\mathrm{NH}_{4}\right)_{2} \mathrm{SO}_{4}$ was more difficult to form than $\mathrm{NH}_{4} \mathrm{NO}_{3}$ did during the Asian dust storm event, or the formation of ammonium sulfate/bisufate might be suppressed as sulfuric acid was taken up by mineral particles (Zhang et al., 1999, 2003), and that, on the other hand, $\mathrm{NH}_{4} \mathrm{HSO}_{4} /\left(\mathrm{NH}_{4}\right)_{2} \mathrm{SO}_{4}$ particles were too small in diameter $(<1 \mu \mathrm{m})$ to be collected by the Dekati $\mathrm{PM}_{10}$ impactor.

\subsubsection{Effects on the relative abundances of carbona- ceous, Fe-rich, fly ash, and other species particles}

Overall, the Asian dust storm event reduced the relative abundances of carbonaceous particles $(1.1 \%$ for the Asian dust samples vs. $4.0 \%$ for the NAD samples in $\mathrm{PM}_{2.5-10}$ fraction and $0.9 \%$ vs. $4.5 \%$ in $\mathrm{PM}_{1.0-2.5}$ fraction) (Table 4). A possible explanation is that the Asian dust mostly originated from the desert and Gobi, carrying a high abundance of mineral dust but not organic compounds (Hwang et al., 2008).

Fe-rich and fly ash particles are not frequently encountered in either the NAD or the Asian dust samples in the MBL (Table 4). The Asian dust samples had higher abundances of both coarse and fine fly ash particles and lower abundances of coarse Fe-rich particles than did the NAD samples. The fly ash particles in the Asian dust samples may have come from east and northeast China (Fig. 3), where there exist several large coal-fired power plants.

In all the samples, only $14(\mathrm{C}, \mathrm{N}, \mathrm{Cl})$-rich particles were encountered. They had low relative abundances except in $\mathrm{PM}_{2.5-10}$ fraction of sample D2, which was collected in the MBL of the Bohai Straits. This type of particle has high atomic concentrations of $\mathrm{C}, \mathrm{N}$, and $\mathrm{Cl}$, and is likely the mixture of $\mathrm{NH}_{4} \mathrm{Cl}$ and organic matter. The release of $\mathrm{HCl}_{(g)}$ from acidified sea salt particles (caused by reaction with $\mathrm{H}_{2} \mathrm{SO}_{4}$ or $\mathrm{HNO}_{3}$ ) could result in elevated concentrations of $\mathrm{HCl}_{(g)}$ available for reaction with dust particles or $\mathrm{NH}_{3}$ (Sullivan et al., 2007).

\subsection{Possible mechanisms for the elevation of nitrogen- containing particles during an Asian dust storm event}

Geographical traits, meteorological conditions, and air mass origins exert significant influences on the chemical compositions of aerosol particles. In this study, it was observed that the Asian dust storm event that occurred on 30 April and 1 May 2006 particularly elevated the relative abundances of secondary soil-derived particles containing nitrates and droplet particles rich in $(\mathrm{C}, \mathrm{N}, \mathrm{O})$. Overall, the relative abundances of these particles gradually increased in the MBL from Bohai Bay to the Bohai Straits and the Yellow Sea. In conclusion, inorganic nitrogen-containing particles in the MBL of the Bohai Sea and the Yellow Sea were enhanced during the Asian dust storm event. The possible reasons are described below.

The Yellow Sea, a semi-enclosed marginal sea of the Northwest Pacific Ocean, joins the Bohai Sea to the north through the Bohai Straits. The aerosols in the MBL of the Bohai Sea and the Yellow Sea are influenced by air masses mostly from mainland China and the Korean peninsula. Inevitably, these aerosols will be also affected by mineral dust and air pollutants carried by Asian dust aerosols. The transport route of a dust storm plays an important role in the effect. In the present study, it is noticeable that the pathway of air 
masses for sample D3 was different from that of air masses for samples D1 and D2, although they all originated from Mongolia and northeast China (Fig. 3). The air masses at heights of $300 \mathrm{~m}, 500 \mathrm{~m}$, and $1000 \mathrm{~m}$ for sample D3 passed over North Korea and the Seoul-Incheon metropolis (while those for samples D1 and D2 just passed over Northern China and the Bohai Sea) and stayed for a shorter period on the sea. Consequently, sample D3 seems to have been more strongly influenced by landmass and metropolis environments than by marine environments, in contrast to samples D1 and D2. This may be why sample D3 contained more secondary soilderived species and (C, N, O)-rich droplets.

In East Asia, due to rapidly growing agricultural, livestock-farming, and industrial activities, particularly in China, the concentrations of $\mathrm{NH}_{3}$ and $\mathrm{NO}_{x}$ species have rapidly increased, leading to a large amount of $\mathrm{NH}_{4} \mathrm{NO}_{3}$ being formed in the East Asian atmosphere (e.g., over the Yellow Sea) (Kim et al., 2006). Large amounts of $\mathrm{NH}_{3}$ are emitted from regions of high agricultural activity and livestock farming (e.g., Shandong, Anhui, Jiangsu, Henan, Sichuan, and Hebei provinces, China), whereas $\mathrm{NO}_{\mathrm{x}}$ is largely emitted from urban areas (e.g., the Seoul, Beijing, and Shanghai areas) (Kim et al., 2006). The mean $\mathrm{NO}_{2}$ values at roadsides in Seoul (60 ppb or so) and Incheon (45.4 ppb) were higher than those in other cities such as Greater Manchester in the UK (33.2 ppb), Rotterdam in the Netherlands (20.8 ppb), Munich in Germany (17.2 ppb), and Stockholm in Sweden (15.1 ppb) (Pandey et al., 2008), providing favorable atmospheric conditions for particulate nitrate formation in the atmosphere. Song et al. (2009) reported that $\mathrm{NH}_{3}$ concentrations in the Seoul atmosphere were also high, ranging from $0.7 \mathrm{ppbv}$ to $13.6 \mathrm{ppbv}$ with an average of $(4.7 \pm 2.1) \mathrm{ppbv}$, and they attributed high concentrations of $\mathrm{NH}_{3}$ to the catalytic converters of automobiles. Hence, it is not unexpected that the air masses passing over the Seoul-Incheon metropolis can carry a large amount of $\mathrm{NH}_{4} \mathrm{NO}_{3}$. Indeed, Miyazaki et al. (2005) found that particulate nitrate transported from the Asian continent to the western Pacific region was mostly in the form of $\mathrm{NH}_{4} \mathrm{NO}_{3}$. The conversion of $\mathrm{NH}_{3}$ from gas phase to aerosol phase will reduce its dry deposition rate, allowing long-range transport of this nitrogen-containing species.

The anthropogenic $\mathrm{NO}_{\mathrm{x}}$ emitted from mainland China and the Korean peninsula may outweigh the $\mathrm{SO}_{2}$ in the MBL of the Bohai Sea and the Yellow Sea, or it may be that $\mathrm{NH}_{4} \mathrm{NO}_{3}$ is more favorably generated and observed in the springtime than $\left(\mathrm{NH}_{4}\right)_{2} \mathrm{SO}_{4} / \mathrm{NH}_{4} \mathrm{HSO}_{4}$, as inferred from theobservations of many $(\mathrm{C}, \mathrm{N}, \mathrm{O})$-rich but not $(\mathrm{C}, \mathrm{N}, \mathrm{O}, \mathrm{S})$ rich droplet particles and of many nitrate-containing but not sulfate-containing secondary soil-derived particles. Aerosols collected in Asia are different in their chemical compositions from those in Europe and North America because in Asia more coal and biomass is burned, leading to a sharp increase in $\mathrm{NO}_{\mathrm{x}}$ emissions and an excess of $\mathrm{NO}_{2}$ concentrations, especially in the atmosphere over China (Richter et al., 2005). $\mathrm{NO}_{\mathrm{x}}$ emissions are expected to continue to increase (Aki- moto, 2003). At the same time, due to a reduction in industrial coal use and the execution of a series of strict environmental protection policies in China, $\mathrm{SO}_{2}$ emissions are expected to decline, resulting in a reduction in acid deposition in China and even in Japan (Carmichael, et al., 2002). In the spring, Asian dust storms originating in the deserts of Mongolia and China make their way to populated cities, adding dust components to the urban aerosols. In the Asian Pacific Regional Aerosol Characterization Experiment (ACEAsia), it was observed that there were few "pure" particles and a lot of calcium-rich particles coated with secondary nitrates; such nitrate-coated particles unexpectedly outnumbered those coated with secondary sulfates, indicating that the Asian dust storm studied in that experiment carried a variety of nitrogen-containing pollutants along with the minerals (Erickson, 2002). Tang et al. (2004) also reported that higher concentrations of sulfate were prevalent in the interior of China, while nitrate and ammonium were maximal at the east coast. The higher $\mathrm{NO}_{\mathrm{x}}$ and lower $\mathrm{SO}_{2}$ emissions in the coastal region might lead to the formation of a large amount of inorganic nitrogen-containing particles.

\section{Conclusions}

Six sets of aerosol samples were collected in the Marine Boundary Layer (MBL) of the Bohai Sea and the Yellow Sea from 28 April 2006 to 1 May 2006 using a three-stage cascade Dekati PM10 impactor. Samples D1, D2, and D3 were collected during an Asian dust storm event whereas samples N1, N2, and N3 were collected on non-Asian dust (NAD) days. Overall, 1800 coarse and fine particles (aerodynamic cutoff diameters: $2.5-10 \mu \mathrm{m}$ and $1.0-2.5 \mu \mathrm{m}$, respectively) were analyzed using a quantitative single particle analytical technique called low- $Z$ particle EPMA. Based on the X-ray spectral and SEI data, 15 types of particles were characterized. For all the samples, soil-derived particles (alminosilicates, $\mathrm{SiO}_{2}$, and $\mathrm{CaCO}_{3}$ ) were the most abundantly encountered, followed by $(\mathrm{C}, \mathrm{N}, \mathrm{O})$-rich droplet particles (likely the mixture of organic matter and $\mathrm{NH}_{4} \mathrm{NO}_{3}$ ), marine particles, and then carbonaceous, Fe-rich, fly ash, and $(\mathrm{C}, \mathrm{N}, \mathrm{O}, \mathrm{S})$-rich droplet (likely the mixture of organic matter and $\left.\mathrm{NH}_{4} \mathrm{HSO}_{4} /\left(\mathrm{NH}_{4}\right)_{2} \mathrm{SO}_{4}\right)$ particles. During the Asian dust storm event, primary soil-derived particles decreased and secondary particles, especially those containing nitrates, increased. Moreover, the relative abundance of the $(\mathrm{C}, \mathrm{N}$, O)-rich droplet particles was elevated in both $\mathrm{PM}_{2.5-10}$ and $\mathrm{PM}_{1.0-2.5}$ fractions, and the abundances of carbonaceous and (C, N, O, S)-rich droplet particles were reduced. The results imply that Asian dust aerosols were an important carrier of gaseous inorganic nitrogen-containing species (within 1.0$10 \mu \mathrm{m}$ ), especially $\mathrm{NO}_{\mathrm{x}}$ (or $\mathrm{HNO}_{3}$ ) and $\mathrm{NH}_{3}$, in the MBL of the Bohai Sea and the Yellow Sea. Considering the potential increases in the emissions of $\mathrm{NO}_{\mathrm{x}}$ and $\mathrm{NH}_{3}$ in the coastal cities of mainland China and Korea, the influences of nitrate 
and ammonium on the biogeochemistry of the Bohai Sea and Yellow Sea are expected to be further enhanced.

Acknowledgements. This work was supported by the Korea Science and Engineering Foundation (KOSEF) grant funded by the Korea government (MOST) (ROA-2007-000-20030-0).

Edited by: N. Mihalopoulos

\section{References}

Akimoto, H.: Global air quality and pollution, Science, 302, 17161719, 2003.

Andreae, M. O., Charlson, R. J., Bruynseels, F., Storms, H., van Grieken, R. E., and Maenhaut, W.: Internal mixture of sea salt, silicates and excess sulfate in marine aerosols, Science, 232, 1620-1623, 1986.

Athanasopoulou, E., Tombrou, M., Pandis, S. N., and Russell, A. G.: The role of sea-salt emissions and heterogeneous chemistry in the air quality of polluted coastal areas, Atmos. Chem. Phys., 8, 3807-3841, 2008

Bergstrom, A.-K. and Jansson, M.: Atmospheric nitrogen deposition has caused nitrogen enrichment and eutrophication of lakes in the northern hemisphere, Global Change Biol., 12, 635-643, 2006.

Bishop, J. K. B., Davis, R. E., and Sherman, J. T.: Robotic observations of dust storm enhancement of carbon biomass in the North Pacific, Science, 298, 817-821, 2002.

Carmichael, G. R., Streets, D. G., Calori, G., Amann, M., Jacobson, M. Z., Hansen, J., and Ueda, H.: Changing trends in sulfur emissions in Asia: implications for acid deposition, air pollution, and climate, Environ. Sci. Technol., 36, 4707-4713, 2002.

Chen, Y., Shah, N., Huggins, F. E., Huffman, G. P., and Dozier, A.: Characterization of ultrafine coal fly ash particles by energyfiltered TEM, J. Microsc., 217, 225-234, 2004.

Chen, Y., Shah, N., Huggins, F. E., and Huffman, G. P.: Characterization of ambient airborne particles by energy-filtered transmission electron microscopy, Aerosol. Sci. Technol., 39, 509-518, 2005a.

Chen, Y., Shah, N., Braun, A., Huggins, F. E., and Huffman, G. P.: Electron microscopy investigation of carbonaceous particulate matter generated by combustion of fossil fuels, Energy Fuels, 19, 1644-1651, 2005b.

de Hoog, J., Osan, J., Szaloki, I., Eyckmans, K., Worobiec, A., Ro, C.-U., and Van Grieken, R.: Thin-window electron probe Xray microanalysis of individual atmospheric particles above the North Sea, Atmos. Environ., 39, 3231-3242, 2005.

Erickson, B. E.: Dust storm provides clues to aerosol mixing, Environ. Sci. Technol., 36, 57A-58A, 2002.

Fan, X., Okada, K., Nimura, N., Kai, K., Arao, K., Shi, G. Y., Qin, Y., and Mitsuta, Y.: Mineral particles collected in China and Japan during the same Asian dust-storm event, Atmos. Environ., 30, 347-351, 1996.

Fang, M., Zheng, M., Wang, F., Chim, K. S., and Kot, S. C.: The long-range transport of aerosols from Northern China to Hong Kong - a multitechnique study, Atmos. Environ., 33, 1803-1817, 1999.

Feng, J., Guo, Z., Chan, C. K., and Fang, M.: Properties of organic matter in PM2.5 at Changdao Island, China - a rural site in the transport path of the Asian continental outflow, Atmos. Environ., 41, 1924-1935, 2007.

Gard, E. E., Kleeman, M. J., Gross, D. S., Hughes, L. S., Allen, J. O., Morrical, B. D., Fergenson, D. P., Dienes, T., Gälli, M. E., Johnson, R. J., Cass, G. R., and Prather, K. A.: Direct observation of heterogeneous chemistry in the atmosphere, Science, 279, 1184-1187, 1998.

Hatakeyama, S., Takamia, A., Wang, W., and Tang, D.: Aerial observation of air pollutants and aerosols over Bo Hai, China, Atmos. Environ., 39, 5893-5898, 2005.

Hwang, H. J. and Ro, C.-U.: Direct observation of nitrate and sulfate formations from mineral dust and sea-salts using low-Z particle electron probe X-ray microanalysis, Atmos. Environ., 40, 3869-3880, 2006.

Hwang, H., Kim, H. K., and Ro, C.-U.: Single-particle characterization of aerosol samples collected before and during an Asian dust storm in Chuncheon, Korea, Atmos. Environ., 42, 87388746, 2008.

Jeong, J.-I. and Park, S.-U.: Interaction of gaseous pollutants with aerosols in Asia during March 2002, Sci. Total. Environ., 392, 262-276, 2008.

Jickells, T. D., An, Z. S., Andersen, K. K., Baker, A. R., Bergametti, G., Brooks, N., Cao, J. J., Boyd, P. W., Duce, R. A., Hunter, K. A., Kawahata, H., Kubilay, N., laRoche, J. , and Liss, P. S., Mahowald, N., Prospero, J. M., Ridgwell, A. J., Tegen, I., and Torres, R.: Global iron connections between desert dust, ocean biogeochemistry, and climate, Science, 308, 67-71, 2005.

Jurado, E., Dachs, J., Duarte, C. M., and Simo, R.: Atmospheric deposition of organic and black carbon to the global oceans, Atmos. Environ., 42, 7931-7939, 2008.

Kim, J. Y., Song, C. H., Ghim, Y. S., Won, J. G., Yoon, S. C., Carmichael, G. R., and Woo, J.-H.: An investigation on $\mathrm{NH}_{3}$ emissions and particulate $\mathrm{NH}_{4}^{+}-\mathrm{NO}_{3}^{-}$formation in East Asia, Atmos. Environ., 40, 2139-2150, 2006.

Krivacsy, Z., Kiss, G., Ceburnis, D., Jennings G., Maenhaut, W., Salma, I., and Shooter, D.: Study of water-soluble atmospheric humic matter in urban and marine environments, Atmos. Res., 87, 1-12, 2008.

Lan, T. T .N., Thoa N. T. P., Nishimura R., Tsujino Y., Yokoi M., and Maeda Y.: New model for the sulfation of marble by dry deposition sheltered marble - the indicator of air pollution by sulfur dioxide, Atmos. Environ., 39, 913-920, 2005.

Laskin, A., Gaspar, D. J., Wang W., Hunt, S. W., Cowin, J. P., Colson, S. D., and Finlayson-Pitts, B. J.: Reactions at interfaces as a source of sulfate formation in sea-salt particles, Science, 301, 340-344, 2003.

Lee, S. B., Bae, G. N., Moon, K. C., and Kim Y. P.: Characteristics of TSP and $\mathrm{PM}_{2.5}$ measured at Tokchok Island in the Yellow Sea, Atmos. Environ., 36, 5427-5435, 2002.

Lin, C.-Y., Wang, Z., Chen, W.-N., Chang, S.-Y., Chou, C. C. K., Sugimoto, N., and Zhao, X.: Long-range transport of Asian dust and air pollutants to Taiwan: observed evidence and model simulation, Atmos. Chem. Phys., 8, 2717-2728, 2008, http://www.atmos-chem-phys.net/8/2717/2008/.

Ma, C.-J., Kasahara, M., Holler, R., and Kamiya, T.: Characteristics of single particles sampled in Japan during the Asian dust-storm period, Atmos. Environ., 35, 2707-2714, 2001.

McInnes, L. M., Covert, D. S., Quinn, P. K., and Germani, M. S.: Measurements of chloride depletion and sulfur enrichment 
in individual sea-salt particles collected from the remote marine boundary layer, J. Geophys. Res., 99, 8257-8268, 1994.

Miyazaki, Y., Kondo, Y., Takegawa, N., Weber, R. J., Koike, M., Kita, K., Fukuda, M., Ma, Y., Clarke, A. D., Kapustin, V. N., Flocke, F., Weinheimer, A. J., Zondlo, M., Eisele, F. L., Blake, D. R., Liley, B.: Contribution of particulate nitrate to airborne measurements of total reactive nitrogen, J. Geophys. Res., 110, D15304. doi:10.1029/2004JD005502, 2005.

Nishikawa, M., Kanamori, S., Kanamori, N., and Mizoguchi, T.: Kosa aerosol as eolian carrier of anthropogenic material, Sci. Total. Environ., 107, 13-27, 1991.

Oum, K. W., Lakin, M. J., DeHaan, D. O., Brauers, T., and Finlayson-Pitts, B. J.: Formation of molecular chlorine from the photolysis of ozone and aqueous sea-salt particles, Science, 279, 74-77, 1998.

Pandey, S. K., Kim, K. H., Chung, S. Y., Cho, S. J., Kim M. Y., and Shon Z. H.: Long-term study of $\mathrm{NO}_{\mathrm{x}}$ behavior at urban roadside and background locations in Seoul, Korea, Atmos. Environ., 42, 607-622, 2008.

Park, M. H., Kim, Y. P., and Kang, C. H.: Aerosol composition change due to dust storm: measurements between 1992 and 1999 at Gosan, Korea, Water, Air, and Soil Pollution: Focus, 3, 117128, 2003.

Ramanathan, V., Crutzen, P. J., Kiehl, J. T., and Rosenfeld, D.: Aerosols, climate, and the hydrological cycle, Science, 294, 2119-2124, 2001.

Richter, A., Burrows, J., Nub, H., Granier, C., and Niemeier, U.: Increase in tropospheric nitrogen dioxide over China observed from space, Nature, 437, 129-132, 2005.

Ro, C.-U., Osan, J., and Van Grieken, R.: Determination of low-Z elements in individual environmental particles using windowless EPMA, Anal. Chem., 71, 1521-1528, 1999.

Ro, C.-U., Osan, J., Szaloaki, I., Oh, K. Y., and Van Grieken, R.: Determination of chemical species in individual aerosol particles using ultrathin window EPMA, Environ. Sci. Technol., 34, 30233030, 2000.

Ro, C.-U., Oh, K. Y., Kim, H. K., Kim, Y. P., Lee, S. B., Kim, K. H., Chang, H. K., Osan, J., de Hong, J., Worobiec, A., and Van Grieken, R.: Single-particle analysis of aerosols at Cheju Island, Korea, using low-Z electron probe X-ray microanalysis: A direct proof of nitrate formation from sea salts, Environ. Sci. Technol., 35, 4487-4494, 2001a.

Ro, C.-U., Oh, K.-Y., Kim, H., Chun, Y.-S., Osan, J., de Hoog, J., and Van Grieken, R.: Chemical speciation of individual atmospheric particles using low-Z electron probe X-ray microanalysis: characterizing "Asian Dust" deposited with rainwater in Seoul, Korea, Atmos. Environ., 35, 4995-5005, 2001 b.

Ro, C.-U., Kim, H., Oh, K. Y., Yea, S. K., Lee, S. B., Jang, M., and Van Grieken, R.: Single-particle characterization of urban aerosol particles collected in three Korean cites using low-Z electron probe X-ray microanalysis, Environ. Sci. Technol., 36, 4770-4776, 2002.

Ro, C.-U., Osan, J., Szaloki, I., de Hoog, J., Worobiec, A., and Van Grieken, R.: A Monte Carlo program for quantitative electroninduced X-ray analysis of individual particles, Anal. Chem., 75, 851-859, 2003.

Ro, C.-U., Kim, H. K., and Van Grieken, R.: An expert system for chemical speciation of individual particles using low-Z particle electron probe X-ray microanalysis data, Anal. Chem., 76, 1322-
1327, 2004.

Ro, C.-U., Hwang, H., Kim, H., Chun, Y., and Van Grieken, R.: Single-particle characterization of four "Asian Dust" samples collected in Korea, using low- $Z$ particle electron probe X-ray microanalysis, Environ. Sci. Technol., 39, 1409-1419, 2005.

Sorooshian, A., Murphy, S. M., Hersey, S., Gates, H., Padro, L. T., Nenes, A., Brechtel, F. J., Jonsson, H., Flagan, R. C., and Seinfeld, J. H.: Comprehensive airborne characterization of aerosol from a major bovine source, Atmos. Chem. Phys., 8, 5489-5520, 2008, http://www.atmos-chem-phys.net/8/5489/2008/.

Su, J., Huang, J., Fu, Q., Minnis, P., Ge, J., and Bi, J.: Estimation of Asian dust aerosol effect on cloud radiation forcing using $\mathrm{Fu}-$ Liou radiative model and CERES measurements, Atmos. Chem. Phys., 8, 2763-2771, 2008

Sullivan, R. C., Guazzotti, S. A., Sodeman, D., A., Tang, Y., Carmichael, G. R., and Prather, K. A.: Mineral dust is a sink for chlorine in the marine boundary layer, Atmos. Environ., 41, 7166-7179, 2007.

Song, C. H., Park M. E., Lee E. J., Lee J. H., Lee B. K., Lee D. S., Kim, J., Han, J. S., Moone K. J., and Kondo, Y.: Possible particulate nitrite formation and its atmospheric implications inferred from the observations in Seoul, Korea, Atmos. Environ., 43, 2168-2173, 2009.

Tang, Y. H., Carmichael, G. R., Seinfeld, J. H., Dabdub, D., Weber, R. J., Huebert, B., Clarke, A. D., Guazzotti, S. A., Sodeman, D. A., Prather, K. A., Uno, I., Woo, J. H., Yienger, J. J., Streets, D. G., Quinn, P. K., Johnson, J. E., Song, C. H., Grassian, V. H., Sandu, A., Talbot, R. W., and Dibb, J. E.: Three dimensional simulations of inorganic aerosol distributions in east Asia during spring 2001, J. Geophys. Res., 109, D19S23, doi:10.1029/2003JD004201, 2004.

Tsuji, K., Nakano, K., Hayashi, H., Hayashi, K., and Ro, C.-U.: X-Ray Spectrometry, Anal. Chem., 80, 4421-4454, 2008.

Vekemans, B., Janssens, K., Vincze, L., Adams, F., and Van Espen, P.: Analysis of X-ray spectra by iterative least aquares (AXIL): new developments, X-Ray Spectrum., 23, 278-285, 1994.

Vester, B. P., Ebert, M., Barnert, E. B., Schneider, J., Kandler, K., Schutz, L., and Weinbruch, S.: Composition and mixing state of the urban background aerosol in the Rhein-Main area (Germany), Atmos. Environ., 41, 6102-6115, 2007.

Wang, Y., Zhuang, G., Tang, A., Zhang, W., Sun, Y., Wang, Z., and An, Z.: The evolution of chemical components of aerosols at five monitoring sites of China during dust storms, Atmos. Environ., 41, 1091-1106, 2007.

Wang, S. D., Shen, Y. M., Guo Y. K., and Tang, J.: Threedimensional numerical simulation for transport of oil spills in seas, Ocean Eng., 35, 503-510, 2008.

Wang, G., Kawamura, K., and Lee, M.: Comparison of organic compositions in dust storm and normal aerosol samples collected at Gosan, Jeju Island, during spring 2005, Atmos. Environ., 43, 219-227, 2009.

Wu, P. M. and Okada, K.: Nature of coarse nitrate particles in the atmosphere: a single particle approach, Atmos. Environ., 28, 2053-2060, 1994.

Yang, G. P., Zhang, H. H., Su, L. P., Zhou, L. M.: Biogenic emission of dimethylsulfide (DMS) from the North Yellow Sea, China and its contribution to sulfate in aerosol during summer, Atmos. Environ., 43, 2196-2203, 2009.

Zhang, D. and Iwasaka, Y.: Nitrate and sulfate in individual Asian 
dust-storm particles in Beijing, China in spring of 1995 and 1996, Atmos. Environ., 33, 3213-3223, 1999.

Zhang, D., Zang, J., Shi, G., Iwasaka, Y., Matsuki, A., and Trochkine, D.: Mixture state of individual Asian dust particles at a coastal site of Qingdao, China, Atmos. Environ., 37, 38953901, 2003.

Zhang, G. S., Zhang, J., and Liu, S. M.: Characterization of nutrients in the atmospheric wet and dry deposition observed at the two monitoring sites over Yellow Sea and East China Sea, J. Atmos. Chem., 57, 41-57, 2007.
Zhao, T. L., Gong, S. L., Zhang, X. Y., and Jaffe D. A.: Asian dust storm influence on North American ambient PM levels: observational evidence and controlling factors, Atmos. Chem. Phys., 8, 2717-2728, 2008, http://www.atmos-chemphys.net/8/2717/2008/. 